\title{
The soucoupes of the Observatoire cave (Principality of Monaco): contribution to the study of the Large flake phenomenon in the early Palaeolithic
}

Les soucoupes de l'Observatoire (Principauté de Monaco) : contribution à

l'étude du phénomène des grands éclats au Paléolithique ancien

Guillaume Porraz, Élisa Nicoud, Michel Grenet and Patrick Simon

\section{OpenEdition}

Journals

\section{Electronic version}

URL: http://journals.openedition.org/paleo/3014

DOI: 10.4000/paleo.3014

ISSN: 2101-0420

\section{Publisher}

SAMRA

\section{Printed version}

Date of publication: 28 December 2014

Number of pages: $195-232$

ISSN: $1145-3370$

Electronic reference

Guillaume Porraz, Élisa Nicoud, Michel Grenet and Patrick Simon, «The soucoupes of the Observatoire cave (Principality of Monaco): contribution to the study of the Large flake phenomenon in the early Palaeolithic », PALEO [Online], 25 | 2014, Online since 28 July 2015, connection on 07 July 2020. URL http://journals.openedition.org/paleo/3014 ; DOI : https://doi.org/10.4000/paleo.3014

This text was automatically generated on 7 July 2020. 


\section{The soucoupes of the Observatoire cave (Principality of Monaco): contribution to the study of the Large flake phenomenon in the early Palaeolithic}

Les soucoupes de l'Observatoire (Principauté de Monaco) : contribution à

l'étude du phénomène des grands éclats au Paléolithique ancien

Guillaume Porraz, Élisa Nicoud, Michel Grenet and Patrick Simon

The study of the large flakes became obvious to us as we reviewed the upper Palaeolithic collections of the Observatory, in the context of the PCR ETICALP led by D. Binder, whom we thank. This study benefited from funding from the Alexander von Humdoldt Foundation, as part of a postdoctoral project led at the University of Tubingen. Thank you to Mr Henry de Lumley for his prior approval for the study of the flakes stored at the Institute of Human Paleontology and to Mrs. Amélie Vialet for her welcome. Also thank you to Mr Michel Olive, for the photographs of the Observatory, to Mr. Michel Dagnino and Jean-Francois Bussiere for photographs of the lithic material as well as to Mr François Burle for the CAD in figures 3 and 23. Thanks to Pierre-Jean Texier for his advice and tricks about the calculation of the curvature radii. Finally thank you to two reviewers for helping to lighten and brighten the content of this article.

\section{Introduction}

Several studies have recently highlighted how the early Palaeolithic, of which the Acheulean is a component, remained a poorly known period marked by strong geographical and also temporal diversity (Nicoud 2010, 2011, 2013a, 2013b; Chevrier 2012a, 2012b; Rocca 2013). This diversity takes issue with the idea of an orderly succession of technical types evolving together with the hominids and their 
environment. One of the challenges of studying this early Palaeolithic is then to adapt its scales of analysis to the construction of a long term argument.

2 Of the technical features that define the early Palaeolithic, macrolithism is certainly one of the most characteristic. This macrolithism, which is neither exclusive nor constitutive of this period, usually carries ideas of mass and shaping generally associated with tools such as handaxes, cleavers and other bolas (Tixier et al. 1980; Texier 1996). But this technical phenomenon defines a rather singular field of investigation. Whether the question of uses, or that of societal organization and representations are considered, the characteristics structuring and structured by macrolithism carry in themselves a significance that should help us recognize better these past societies.

3 The debitage of large flakes is a macrolithic manifestation that crosses the early Palaeolithic (Sharon 2007; Mourre and Colonge 2010). This usually involved a shaping chaîne opératoire, but it also appears to exist by itself in certain contexts. Studying these large flakes allowed the recognition of several modes of production, some being close to the principles of the Levallois concept (Mourre 2006; Sharon 2009). The concept of predetermination is specifically revealed in the cleavers chaines opératoires, whose full expression was achieved during the Middle Pleistocene (Mourre 2003). The temporal and geographic distribution of these large flakes led to formulate various hypotheses about their origin and future. In Western Europe, this technical phenomenon would be limited to the Iberian Peninsula and its margins under the privileged form of a first flake debitage associated with type 0 cleavers (Sharon 2007). It is on the basis of this techno-typological distribution that the hypothesis of the diffusion of an Acheulean from North Africa toward Spain via the Strait of Gibraltar has been proposed (Bordes 1966; Alimen 1975; Tavoso 1986; Otte 1996; Sharon 2011).

4 As part of a program focusing on the technical successions in the Ligurian-Provençal arc, we were quickly surprised and challenged by the collection of large flakes or "soucoupes" (Boule and Villeneuve 1927), from the Observatory cave (Principality of Monaco). Indeed, comparisons that we were tempted to establish -more or less intuitively- with the assemblages of the Iberian Peninsula supported a new discussion on the expansion area of this technical phenomenon and the meaning of it. What are these soucoupes? Where do they come from?

5 In the present article, we start a detailed description of the large flakes corpus of the Observatory to identify the techno-functional structures, the production rules and their associations. This study allows us firstly to highlight the originality of technical behaviours that are closely tailored to the working materials, and in a second time to discuss the diffusion and local innovation hypotheses within the technical phenomenon of large flakes in the Early Palaeolithic. One of the challenges raised by the Early Palaeolithic study is to adapt successfully its scales of analysis; one of the opportunities is to start a speech about the techniques over a long duration.

\section{Context and integrity of the studied collection}

6 The Observatory cave (Principality of Monaco) is located on the coastline of the liguroProvencal arc, near the Franco-Italian border, at an altitude of $104 \mathrm{~m}$ above the present sea level (fig. 1). The entrance is formed by a large opening cut into the steep wall of the Upper Jurassic limestone formations. It leads to a $500 \mathrm{~m}$ long karst system, sinking 
to a depth of $100 \mathrm{~m}$ below the present surface of its entry. The sedimentary remains trapped in the karst indicate an exposure of the cave since the Calabrian marine transgression (+108 $\mathrm{m}$ ASL in the Nice region), that is to say about $1 \mathrm{Ma}$ BP.

The Observatory cave was discovered during the works of the Exotic Garden of the Principality of Monaco (Boule and Villeneuve 1927). The workers unearthed numerous remains from the Upper Palaeolithic, which quickly attracted the attention of local authorities. The discovery took place in a context where prehistoric research in Provence and Liguria knew a boom following the discoveries made in the Balzi Rossi sector (for review, see: Simon 2008), located $10 \mathrm{~km}$ east of the cave.

Léonce de Villeneuve began to fully excavate the cave, at the request of Prince Albert 1 of Monaco, between 1916 and 1920. The lack of field documentation is of course detrimental to the understanding of the dynamics of the deposits in the site. However, we must recognize the merit of the canon Léonce de Villeneuve and of Marcellin Boule who published their results quickly in a detailed and well-illustrated monograph, which now allows putting into context the archaeological collections. Thus we have revised the lithic collections of the proto-Aurignacian levels of the Observatory cave (Porraz et al. 2010). This is with a similar approach that we are now reporting our results on the oldest archaeological levels.

Luckily for the study of the Observatory cave, two stalagmite floors were present within the sedimentary sequence, identified during the excavation and reported on the study documents (floor I, II: fig 2). Marcellin Boule and Léonce de Villeneuve distinguished three main stages based on the presence of these two floors, called lower group (group 1), middle group (group 2) and upper group (group 3). The deposits that interest our study are those in the lower group, located under floor II (fig. 2).

Figure 1 - Location of the Observatoire Cave (Principality of Monaco) and of the main sites mentioned in the text.

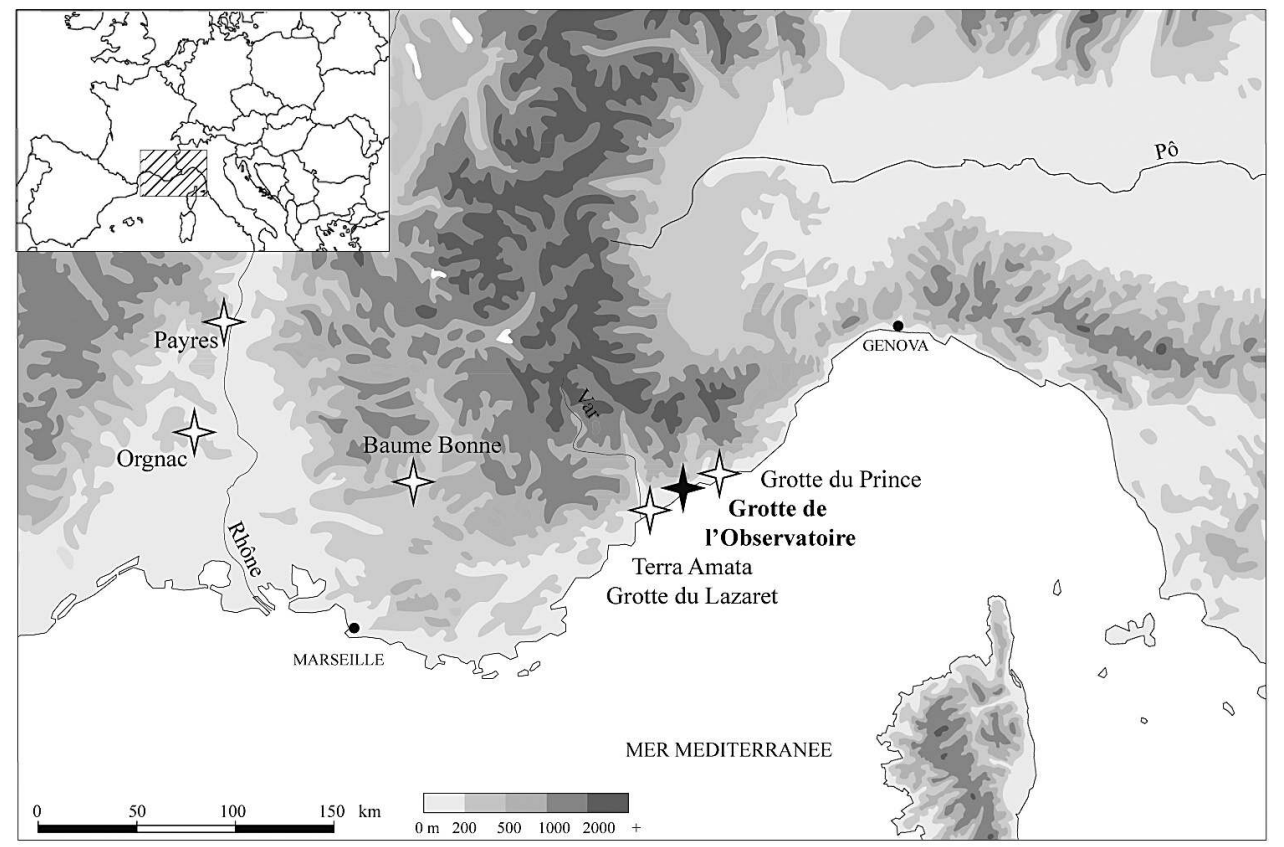


Figure 2 - Stratigraphic context of the lower deposits from the Observatoire Cave and location of the "hearth k" .

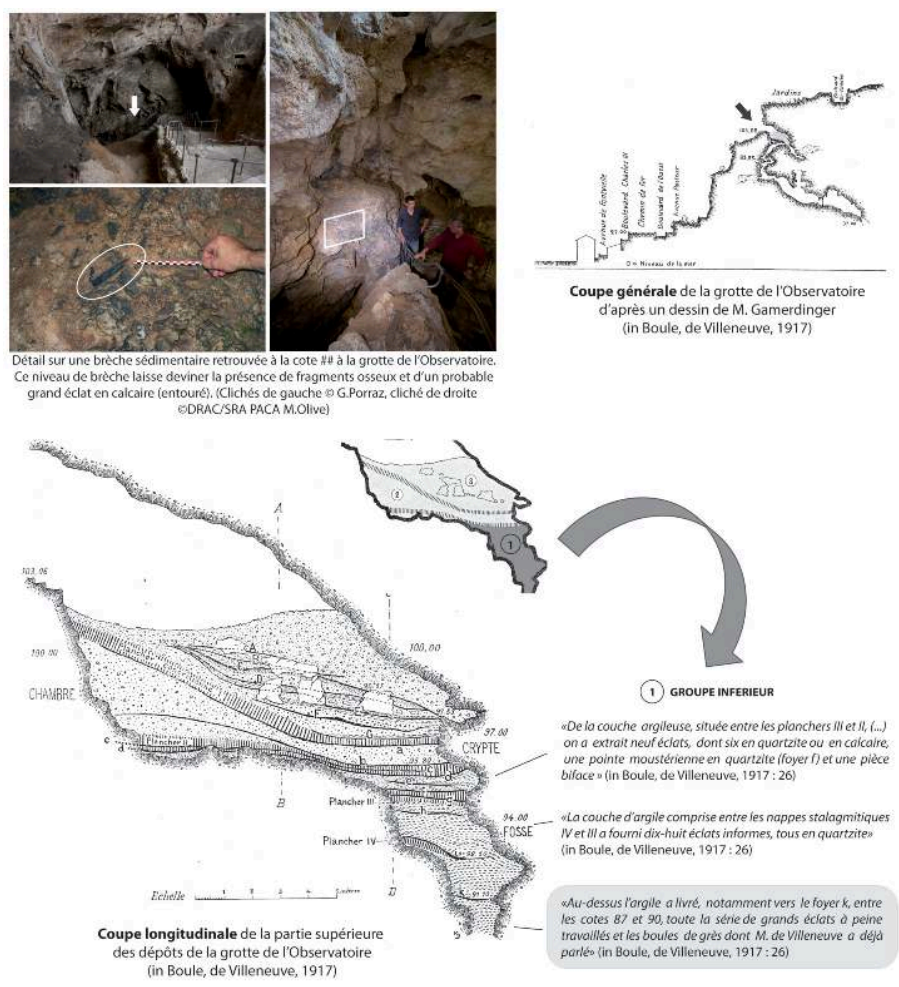

10 We are reporting here the main published material useful to the understanding of this lower group (Boule and Villeneuve 1927 - 25-26 p.):

"The filling elements [are essentially made] of clay or cave earth. (...) This clay mass, highly homogeneous, is cut by two stalagmite formations indicating pauses in the sedimentation, layer IV and the much greater layer III. It is, somehow, sealed by the vast layer II that covers the entire surface of the first filling.

Mr. Villeneuve also noted, in its thickness, several lines of ashes, the oldest of the cave: hearth $\mathrm{k}$ at measurement 91 , hearth i on stalagmitic floor IV (...). We would be tempted to see in these cinder lines or streaks not real undisturbed hearths, but the shifting and levitation of ash accumulations originally located in the entrance of the cave. This hypothesis would explain better the presence of the products of human industry we found there, dispersed in clay (...)"

11 These notes provide a good general understanding of the sedimentary and archaeological situation. First, as we could suppose, the filling of the karst and the accumulation of the material most likely have a colluvial origin. But contrary to the information given in the notes published by Mr. Boule and L. de Villeneuve (1927), there would be a single and unique opening in the karst of the observatory, as indicated in the map at our disposal. This colluvium would therefore find its origin at the level of the current entrance to the cave, likely location of the human occupations.

Moreover, this lower sedimentary "group" has the advantage of being multiphase as evidenced by the non invasive formation of floors III and IV and the presence of several "ash lines" respectively individualised under the hearths $\mathrm{k}$ to e (fig. 2). This phasing finds matches from an archaeostratigraphical perspective. As the authors point out (Boule and Villeneuve 1927 - p. 91): "This industry is not exactly the same from the top 
to the bottom of the group." Three main technological units thus emerge from this lower group, which we individualized by "hearth:"

1. "hearth k:" base deposits have yielded large limestone flakes, hand-carried pebbles and one handaxe: the deposits are between the 86-87 dimensions (not reported in the published stratigraphy) and hearth $\mathrm{k}$ (dimension 91);

2. "hearth h:" intermediate deposits have yielded a group of quartzite flakes between floor IV and floor III;

3. "hearth e:" the deposits of the top yielded flakes, a Mousterian point and two bifacial pieces, between floors III and II.

Therefore, the "hearth $\mathrm{k}$ " collection of large flakes from the Observatory comes from the base of the deposit of the lower group, between the dimensions 86 and 91. This collection is distributed over a height of almost $5 \mathrm{~m}$, with a density of remains reported as low. According to published notes, no archaeological object would have been found between the dimensions 91 and 92, indicating a possible hiatus in the human occupation between the "hearth $\mathrm{k}$ " and " $\mathrm{h}$ ". Our own field observations allowed us to find again a brecciated level that includes bone fragments and a probable limestone large flake (fig. 2). This brecciated level is situated between the dimensions 89 and 91, precisely the altimeter range indicated by Marcellin Boule and Leonce de Villeneuve ${ }^{5}$.

More recently (1984 and 1986-87), S. Simone and P. Simon (Prehistoric Anthropology Museum of Monaco) have initiated an excavation of de Villeneuve likely waste soil of, rejected in one of the karst corridors of the cave. In fact, this excavation focused on the most recent waste, that is to say the oldest archaeological deposits. During this operation, 10 large flakes and large flake fragments and about fifty pebbles were collected, to which must be added numerous small flakes and knapped limestone fragments $(n>40)$.

collection available today includes a total of 350 lithic pieces and has high petrographic and technological homogeneity. The under-representation of the small items is a bias in the analysis, although the origin of this bias is uncertain (excavators and/or settlements, and/or post-depositional process?). Furthermore the presence of a scraper on elongated blank should be noted (pl. XIX, fig.4. : Boule and Villeneuve 1927); it is incongruous in the collection of large limestone flakes. This scraper, which evokes more recent contexts, is made of blue grey flint with much detrital quartz whose origin is to be found in the border geological formations (Tomasso et al. submitted).

\section{The "old Palaeolithic" of the Observatory cave}

The old age of the excavations explains the relative absence of the large flakes of the Observatory in the current debates on the early Palaeolithic of the Mediterranean world and Western Europe. But this cautiousness is also explained by the inherited difficulties in classifying and understanding the nature of this industry.

Marcellin Boule and Léonce de Villeneuve (1927) are the first to comment on this lower group they call "old Palaeolithic" (p. 27), "a very ancient Palaeolithic feature" (p. 91). The authors argue: "We are dealing with an industry of the Early Palaeolithic, containing Chellean, Acheulean and Mousterian shape types " (p. 97). They note the originality of the large flakes and linger with interest on the handaxe with reserved base found in the lower part of the deposits (91-93 p.): 
"These are big yellow, light gray or dark gray limestone flakes, compact in texture, and presenting beautiful percussion bulbs. The largest dimension of these objects may exceed $0.16 \mathrm{~m}$ (saucers or "plates" in Mr. de Villeneuve's text) (...). But the most remarkable object of this first series, which comes from the lowest level reached by the excavations ( 87 meters), is a beautiful amygdaloidal instrument knapped out of a large yellowish limestone pebble with compact homogeneous texture [pl . XIX, fig. 1: in Boule, Villeneuve, 1927]. This is a real "coup-de-poing" elongated, pointy, of Chellean manufacturing (...)."

Soon enough, under the influence of the work of Abbot H. Breuil, the industry of the Observatory cave was associated with the groups of the so-called Clactonian industries, characterized by the presence of "often very large flakes but also medium or small ones, knapped on stone anvil (...). The striking platform is usually very large, and forms a very open angle with the tearing plane" (Breuil 1932 - p. 571). This is the case in the publication of M.G. Pottier on the chronology of the Lower Palaeolithic (1938) that appears to be the first to classify the industry from the Observatory cave in the Clactonian group. In 1954, Abbot H. Breuil and H. Kelley confirm this attribution (p. 17):

"The Observatory cave in Monaco (90 m ASL) yielded at its base a remarkable complex, also knapped into compact limestone, superimposed, several meters apart, to an Abbevillian handaxe; there is a thick Clactonian level, above which were found two Acheulean handaxes. It is therefore certain that Clactonian episodes have existed in this region. "

H. de Lumley's research leads him to move away from this chronocultural determination. While acknowledging the existence of similarities with the Clactonian, the author acknowledges a number of differences that justify for him the individualization of the collection of the Observatory (de Lumley 1960 - p. 2):

"The Observatory cave (Principality of Monaco) and the Curson site (Veaunes Valley, a tributary of the lower Isere, Drôme region) provided an industry dominated by large little retouched flakes, knapped from large grey limestone pebbles, with a large striking platform forming a very obtuse angle with the tearing platform. Several authors have compared these industries to that of Clacton from which they differ, however, by various characteristics. At the Observatory, and perhaps in Curson, they seem associated with handaxes (...). We isolate this third group of industry under the term "Curson type. '"

20 The same author offers a more detailed study in his rich typological study of the southern Mediterranean Palaeolithic (de Lumley-Woodyear 1969). In his article on the civilizations of the Lower Palaeolithic (1976), he resumes his main conclusions, moving away from his first interpretive trail (de Lumley 1976 - 834 p.):

"The industry of the Middle Pleistocene deposits of the Observatory cave, knapped in grey limestone, can be defined as a middle Acheulean with an industry on non Levallois debitage flakes, with few retouched tools. The flakes, abundant and large, are mostly preliminary flaking of pebbles and almost always kept part of the cortex. Three handaxes were discovered: with a cortical reserved base and sway-backed edges, lozenge-shaped and flat triangular."

21 Without talking about consensus, it is the attribution to an Acheulean that gradually established itself in the literature (Gagnières 1970; Villa 1983; Cauche 2012). Beyond the semantic content (Nicoud 2013a), we need to remember here the shift that has taken place in the study of the ancient deposits of the Observatory. Indeed, the publications have gradually devoted an overall analysis to the lower group at the expenses of the stratigraphic origins, thus mixing industries from "hearth $\mathrm{k}$ ", "hearth $\mathrm{h}$ " and "hearth e". 

Observatory cave is the result of an analytical bias which was to study the lower
deposits in one piece, without distinguishing the phases that were recognized during the excavation. But this uncertainty is also explained by our ignorance of the lithic intentions and operating chains. Furthermore, the absence of a chronology is similarly detrimental to our overall knowledge of these early occupations. Different ages have been proposed in the literature for older deposits of the Observatory, on the basis of the fauna and inter-sites comparisons. A review of the chronology reports on human occupations that could cover the middle of the Middle Pleistocene until the Upper Pleistocene (de Lumley 1976; Bosinski 2006). To date, two ages are available. This is a sample of floor II dated by Uranium / Thorium to $>178,000$ years and a sample of floor III dated by the same technique to $>230,000$ years BP (Simone 1993). Thus, the production of the large flakes of the Observatory would be contemporary or anterior to the MIS 7 (terminus ante quem).

\section{The lithic assemblage of "hearth $k$ " in the Observatory Cave}

The studied assemblage consists of 132 large flakes, 1 handaxe and 159 unprocessed pebbles. The stratigraphic origin of the large flakes was discussed previously. As for the origin of the handaxe, it is provided by the description specifically given by Marcellin Boule and Léonce de Villeneuve (1927). This handaxe was found at dimension 87 or the lower stratigraphic limit of our study assemblage. Its direct association with the large flakes, mostly collected around dimension 91, can therefore be discussed. About the origin of the unprocessed pebbles, their nature, their homogeneity and the geological context of the cave exclude any accumulation of natural origin (see below). Note that for consistency and clarity of speech, we have removed the flint scraper from the analysis below.

\section{The large flakes from the Observatory}

"The shape of these flakes is quite varied: subtriangular, triangular, discoid, polygonal. The most numerous are unretouched. The others have more or less numerous retouches, distributed more or less regularly. (...) One of the largest specimens of this kind, in gray limestone [fig.14-15: in Boule, Villeneuve 1927] comes from this same dimension 89. Its shape, fairly regular, is that of a rectangle almost a square- rounded at the four corners. One side is formed by the very surface of a huge percussion bulb with a large curvature radius; the other side is divided into two unequal parts by a crest similar to the ridge of a very low gabled roof. The symmetry of this object is accentuated by the presence of secondary facets produced at both ends by removing some flakes that give it the appearance of 
a huge double-scraper. It seems that we have an intentional shape, intentionally

manufactured for a special use" (Boule and Villeneuve 1927 - p. 91-93) scars ( $45 \%$ of the determinable total), flakes with cortical surface and bilateral preparation scars, prepared flakes and finally flakes with cortical back or debitage back. Note that one unique flake shows the use of the ventral face of a blank-flake (Kombewa type). The first striking feature of this assemblage is the high proportion of cortical pieces and the absence of cores. We find ourselves facing a collection of finished products brought into the cave already knapped for a production that is distinguished by the brevity of its operating sequences.

Figure 3 - Large flakes of the hearth $\mathrm{k}$ from the Observatoire Cave and general overview of the types of limestones exploited.

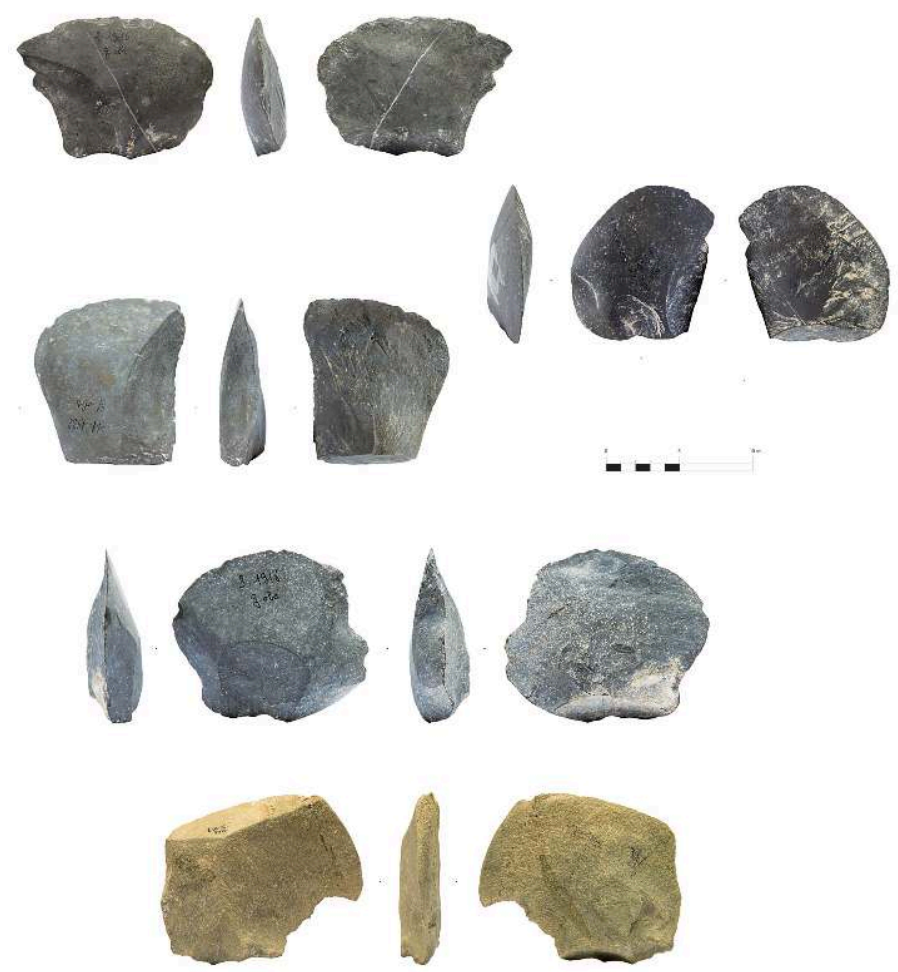


Figure 4 - Technology of the large flakes from the hearth $k$ of the Observatoire Cave.

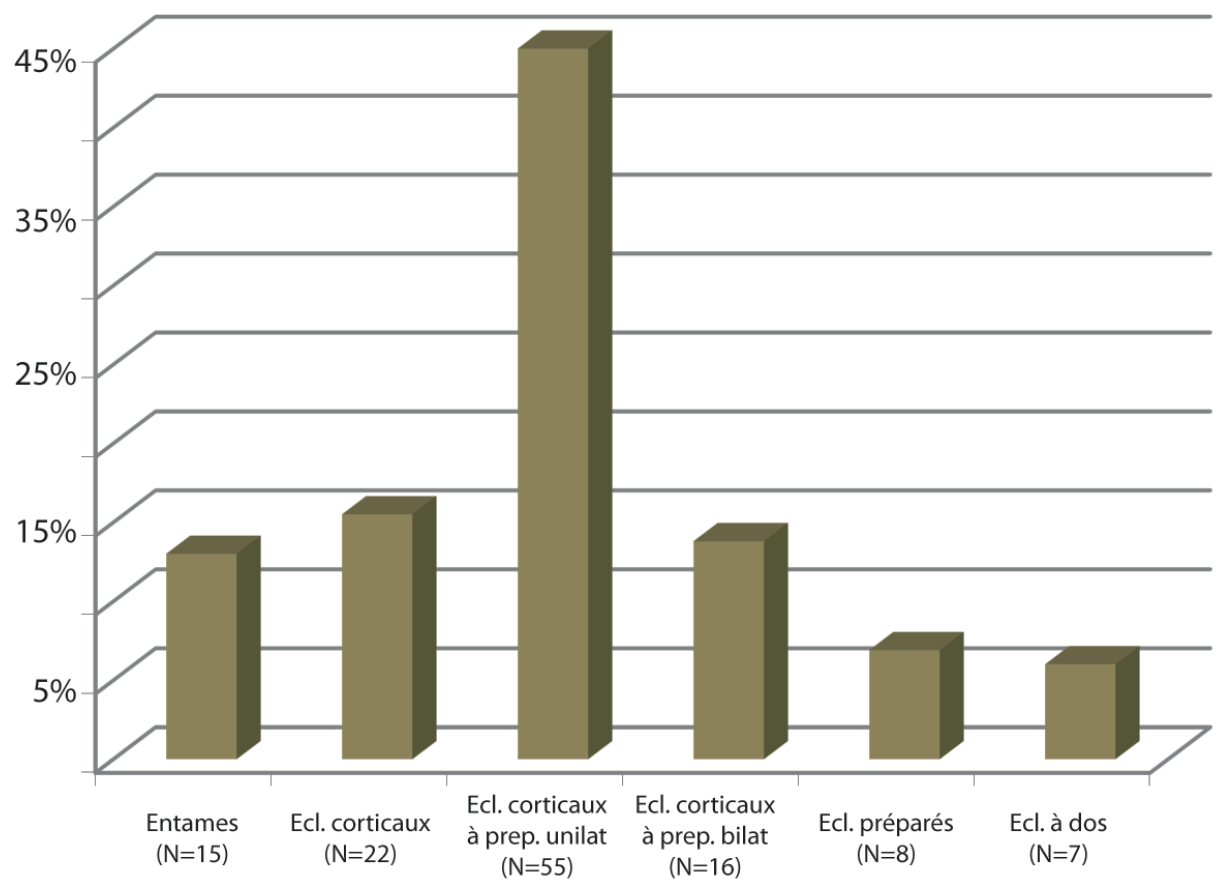

Figure 5 - Boxplots of the length, the width, the thickness and the weight of the large flakes coming from the hearth $k$ of the Observatoire Cave, according to their technological categories
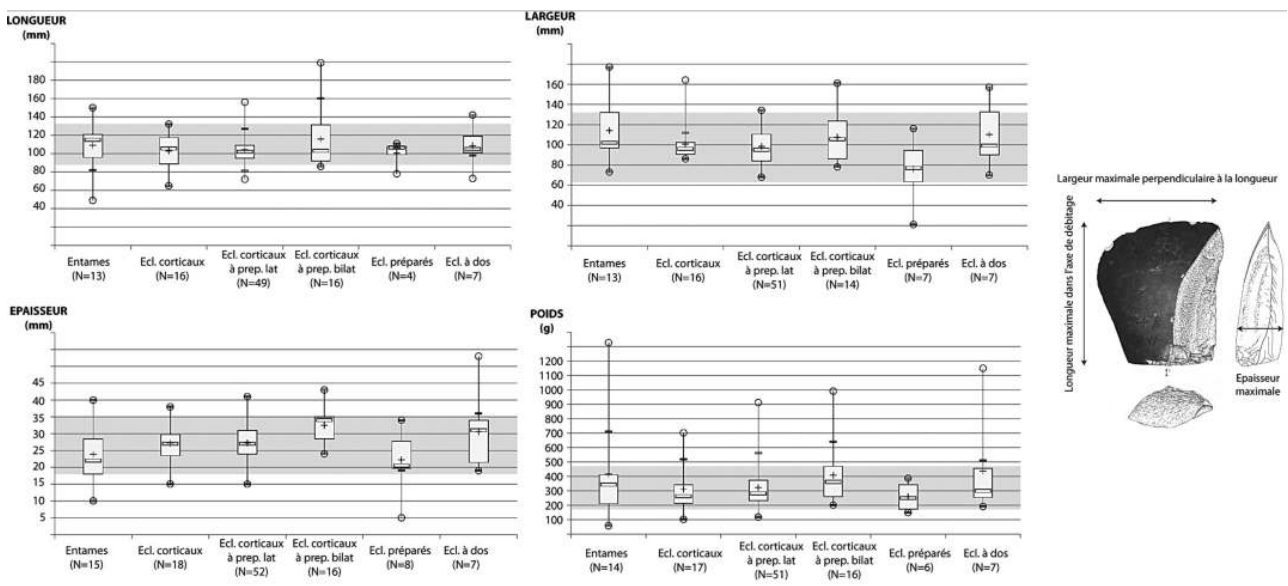

From a morphometric viewpoint these flakes are noticeable by their large size, with an average length of $106 \mathrm{~mm}$ (measured along the debitage axis), a width of $101 \mathrm{~mm}$, a thickness of $28 \mathrm{~mm}$ and an average weight of $345 \mathrm{~g}$ (fig. 5). These flakes cover well the definition of "large flakes" whose threshold is typically set at $100 \mathrm{~mm}$ long (Kleindienst 1962). These metric averages vary only slightly depending on the considered technological categories (fig. 5), supporting the hypothesis of a dimensional (or standard) threshold. However, some flakes stand out by their extreme dimensions, as illustrated by a few rare high mass specimens (> $1000 \mathrm{~g}$ ). In general, these flakes have a rather stocky morphology with an elongation index (L/W taken in the morphological axis) of about 1.2 . 

The standardization of the techno-functional characteristics of this bevel is due
predetermination that has occurred through the respect of 3 main technical rules:

1. Rule 1 concerns the phase of selection of the pebble and the interaction of the knapper with its natural convexity. The study of the large flakes shows that the selected pebbles were not spherical but hemispherical: an asymmetry that orients their volumetric orientation. The flatness index of the pebbles, taken along the axis of percussion of the flakes (fig. 20) shows that the debitage surface was positioned on the less convex natural surface, the percussion waves then ending on weakly marked convexities.

2. Rule 2 was to establish a directing convexity so that the fracture front developed by making the two edges of the flake diverge. This predetermination towards divergence was set up by the removal of predetermining flakes, whether unilateralised and then combined to the natural asymmetry of the opposite edge (fig. 6-9) or bilateralised (fig. 10, No. 1; fig. 11, No. 1; fig. 12). Alternatively, the knappers have taken advantage of the natural morphology of the knapped surface (fig 16, $\mathrm{N}^{\circ} 1$ ) or have prepared the bevel by a predetermining removal negative (fig $13, \mathrm{~N}^{\circ} 1$; fig 14 ).

3. Rule 3 focused on setting up an open breaking platform, with an average angle of about $120^{\circ}$ (fig. 21). This striking platform (fig. 21) has often been prepared by a removal, oblique or perpendicular to the axis of the debitage surface. This results, particularly for flakes with negatives of unilateral preparation, in the presence of a plain "à pan" butt (i.e. fig. 6-7).

The respect of these three rules helped ensure the repetition and standardization of the techno-functional characteristics of the large flakes. Rule 2 is at the origin of the good control of the overall morphology of the tool, namely the presence of a transverse edge, straight to slightly convex, perpendicular to the axis of percussion. Thus the observed variability in the operating modes (unilateralised or bilateralised removals, single or multiple, convergent or orthogonal unipolar lateralised removal, etc), is not interpreted as a reflection of different intentions, but as a suitable operating flexibility adapted to volumes and to a well-defined target size. The inventory shows us that this operating flexibility was aimed more at correcting the transverse convexities than the longitudinal convexities, mentally and naturally prefigured for the future active part of the desired tool. So the knapper, by selecting and directing the pebble, would stabilize the longitudinal convexity then rectify the transversal convexity.

31 The combination of rules 1 and 3 is itself the cause of the normalizing of the section and bevel angle characteristics. The first technical operation was to arrange the techno-functional characteristics by structuring the debitage around a natural flat surface; the second operation was to control the mechanical disruption by promoting a spreading of the percussion waves through the setting up of an open breaking platform and an inward "muffled" percussion gesture (see below). The layout of both technical operations would have favoured some knapping accidents, as evidenced by the "vibrations" frequently observed in the distal part of the flakes, characteristic of the progress of a fracture front at the limit of hinging. 
cortical bevel flakes. These flakes are whether entames ( $N=15$, fig. 15), whether flakes with cortical surface and plain butt $(\mathrm{N}=18)$ whether prepared flakes $(\mathrm{n}=8)$, whether backed flakes ( $n=7$, fig. 17). Nevertheless, the large flakes from the Observatory all seem to belong to a one and single operational chain of debitage: the non-bevelled flakes are then situated before or after the full debitage. This is observed in particular by the dimensions and angles of similar striking platforms than those observed for the cortical bevel flakes, except for the prepared flakes (see below). These non bevelled flakes show varied techno-functional characteristics, though they always associate the presence of a generally convex cutting edge to a plane, opposite or adjacent, natural or from debitage.

\section{The hand-carried pebbles from the Observatory}

\footnotetext{
"We already know that Mr. de Villeneuve has collected, together with this large and primitive lithic industry in limestone and quartzite, numerous "balls" of stone. I have not examined the whole collection, but only four samples chosen at my request by Mr. Lorenzi among those that seemed to him to show some artificial characteristics (...). Of the four samples that I just mentioned, one is made of limestone, the other three of sandstone. Their mean diameter ranges from $0.15 \mathrm{~m}$ to $0.12 \mathrm{~m}$; their weight from 340 to 820 grams. All bear traces of working." (Boule and Villeneuve 1927 - p. 94).
} 
inventory of hand-carried pebbles consists of 159 objects, to which should be added the presence of 4 pebbles bearing debitage traces and 8 cortical flakes bearing the scars of an accidental origin during percussion. These pebbles come for most from the excavations of the Prehistoric Anthropology Museum of Monaco that concentrated on de Villeneuve's possible excavation waste; their stratigraphic origin can therefore be questioned. However, the descriptions published in 1927 (Boule and Villeneuve 1927) only mention unworked pebbles in the context of the large flakes (see above). The large number of flakes de Villeneuve rejected during his excavations would then be explained by doubts about their origin. In this regard, we must mention the presence of 15 pebbles from karstic origin excluded from this study. These pebbles have an irregular morphology (about 50\% of determinable cases), which clearly distinguishes them from the rest of the inventory of sea pebbles (fig. 22). It is mostly small polyhedral blunt blocks in beige dolomitic limestone.

The inventory of hand-carried pebbles shows varying states of preservation (fig. 23). A quarter of the inventory (fig. 22) shows post-depositional alterations of the concretion or flaking type that undermine completely the search of traces of use. Moreover some pebbles seem to have suffered the effects of accidental heating, marked by the presence of localised thermal cupmarks, cracks and flaking.

These alterations have not hampered the petrographic analysis since only 2 specimens remain indeterminate. The spectrum of rocks is largely dominated by limestone making up almost 3/4 of the total (fig. 22), complete with sandstone and andesite. The materials identified broadly reflect the local stratigraphic column mostly with Upper Jurassic pebbles (Kimmeridgian and Tithonian) corresponding to very fine limestone (limestone mud), sometimes called sublithographic limestone (from beige to cream in colour). There are also dolomitic limestones, pulverulent (dolomitisation of the Tithonian) or massive with finer texture (dolomitisation of the Middle Jurassic), some marly limestone of the Upper Cretaceous (most likely Turonian) and a limestone sample with pisolites and glauconite characteristic of the reduced and condensed lower Cretaceous levels of Nice. The sandstones also show some variability, illustrated by more or less coarsely detrital types whose origin is to be found in formations of the "Sandstone of Annot" (Oligocene Flysch) type. There is finally a small quantity that corresponds to the andesite of the volcanic Oligo-Miocene deposits of Cap d'Ail, the andesite pebbles coming from the dismantling of the pyroclastic andesite blocks. All this range of rocks is available on the coastline directly below the cave.

Only one or two pebbles in siliceous sandstone typical of the Werfenian of La Roya could have been collected at the mouth of this small coastal river, which is about fifteen kilometres west of the site

The collection of pebbles seems to have been determined by an exclusively petrographic criterion. Although the limestone group dominates, it has indeed a strong diversity of types that define so many different qualities (i.e. hardness, homogeneity, etc.). Conversely, a certain dimensional homogeneity emerges from this inventory (fig. 22). With few exceptions, they are palm-sized pebbles, which have an average size of about $81 \times 67 \times 55 \mathrm{~mm}$ for an average weight of $455 \mathrm{~g}$, the majority of them having a (sub)ovoid to (sub)triangular morphology (presence of a natural plane) (fig. 22).

41 The preliminary study on the integrity and surface condition of the pebbles allows putting forward the first functional assumptions. At this stage of the study, we are 
distinguishing two main types of traces that are secondary pecking and breakages. Secondary pecking, which can be more or less deep and circumscribed on the surface of the pebble, corresponds to a percussion use on a hard material. It was identified on almost $1 / 3$ of the inventory of unaltered pebbles. The breakages are more difficult to interpret. Some of them, identified on a small sample $(n=4)$, actually correspond to incipient negative removals accidentally detached by percussion. Others find their origin in post-depositional processes. However numerous breakages, initiated in the elongation axis of the pebble or in its thickness, carry no stigma that we are able to interpret. These breakages are definitely anthropogenic, probably unintentional, but the absence of reference and experimentation does not allow going further in this discussion.

A second interesting aspect of the technological analysis is the high proportion of pebbles bearing no trace of use (fig. 22). The null hypothesis would be that the origin of all of the pebbles would be natural, some having been selected perhaps in an opportunistic manner and used. However, we categorically reject this hypothesis. Indeed, the latter would imply that the origin of these marine pebbles is linked to the shifting of ancient brecciated pre-calabrian or Pliocene deposits, situated in the vicinity of the cave and that would therefore have participated in filling the karst. No geological evidence support this hypothesis. Moreover, the dimensional sorting observed in our inventory evokes a spectrum of artificial and not natural origin. The hand-carried pebbles with no trace of wear therefore correspond to little or unused pebbles or to pebbles used on soft materials, plants for example. In the state of our knowledge, it is dangerous to suggest a function and an operating mode for these pebbles. At most we can notice that different kinds of rock were used in percussion, and that different facets of the same pebble could be used during the activity. The issue of mineral management and rock properties is certainly a reflection to explore further. Note that the sandstone pebbles show many more traces of percussion than the limestone ones (respectively about $50 \%$ and $20 \%$ of unworked pebbles). The nature of the activities as well as the rock recording capabilities should help explain the difference.

Finally 4 pebbles, 2 of sandstone, 1 of limestone and 1 of andesite, show traces of debitage on anvil (fig. 23), done in the smallest axis of elongation. None of the small flakes found bear traces of such a debitage, which therefore remains anecdotal in our series. 
Figure 6 - Large flakes with cortical biseau showing an unilateral preparation, hearth $\mathrm{k}$ of the Observatoire Cave (drawings by M. Grenet).

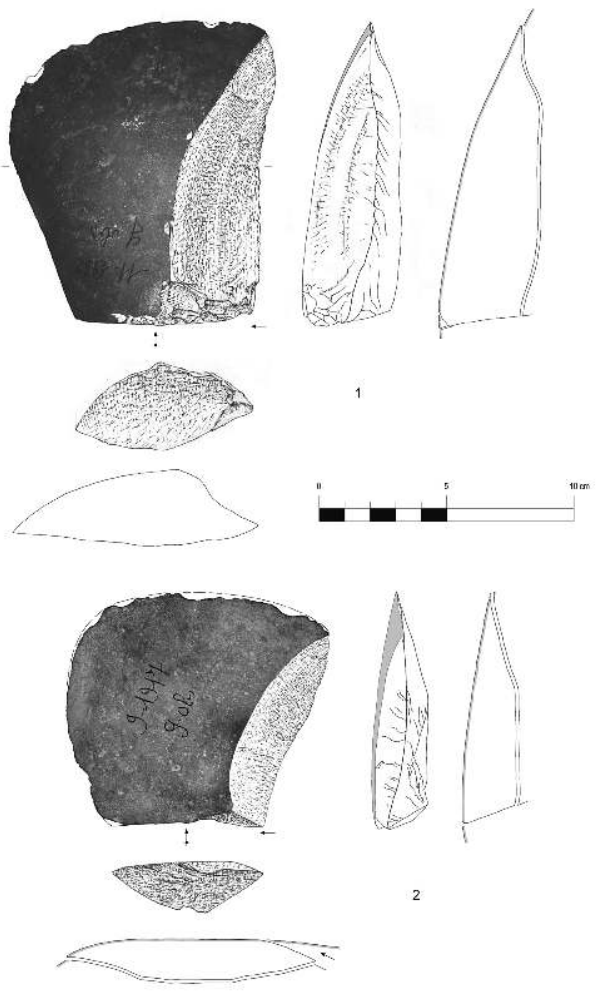

Figure 7 - Large flakes with cortical biseau showing an unilateral preparation, hearth $\mathrm{k}$ of the Observatoire Cave (drawings by $M$. Grenet).

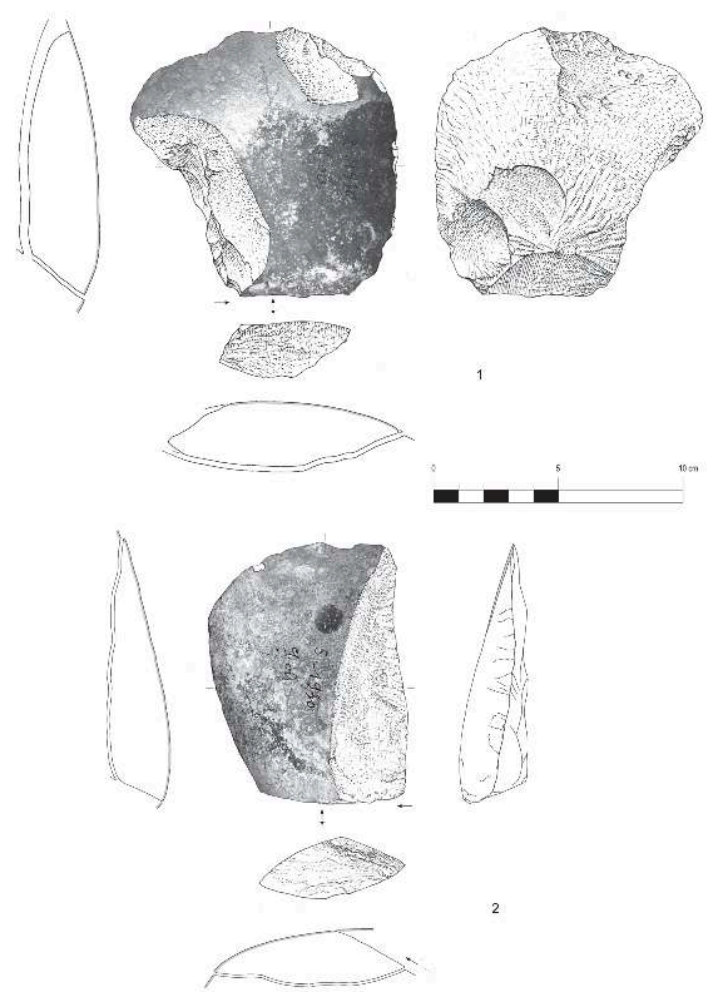


Figure 8 - Large flakes with cortical biseau showing an unilateral preparation, hearth $\mathrm{k}$ of the Observatoire Cave (drawings by M. Grenet).

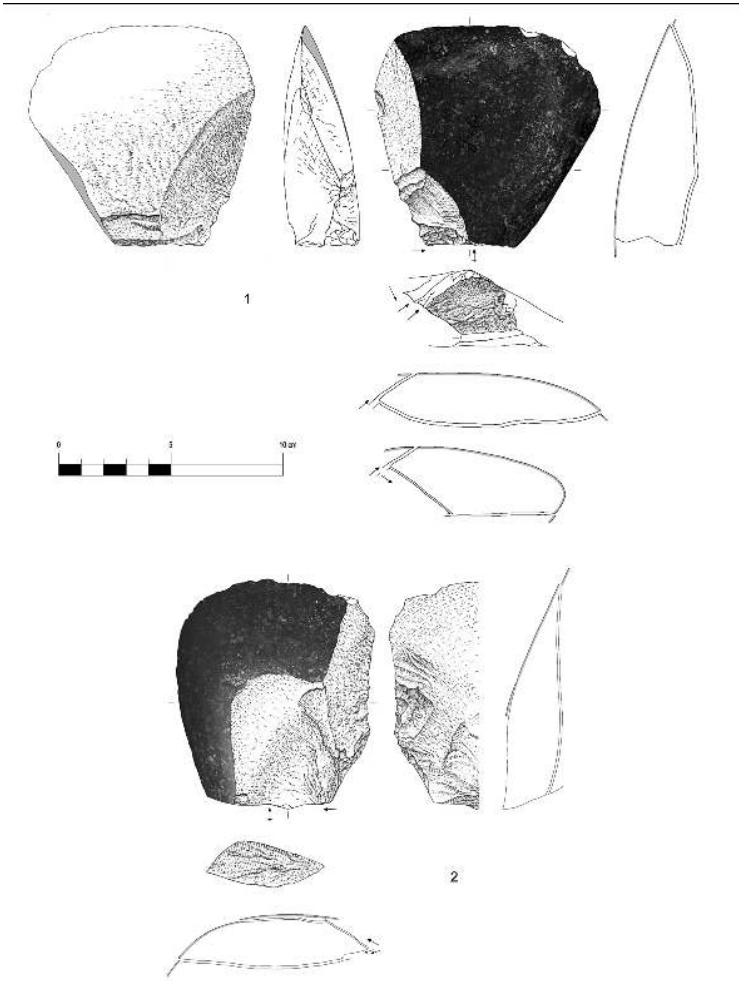

Figure 9 - Large flakes with cortical biseau showing an unilateral preparation, hearth $\mathrm{k}$ of the Observatoire Cave (drawings by M. Grenet).

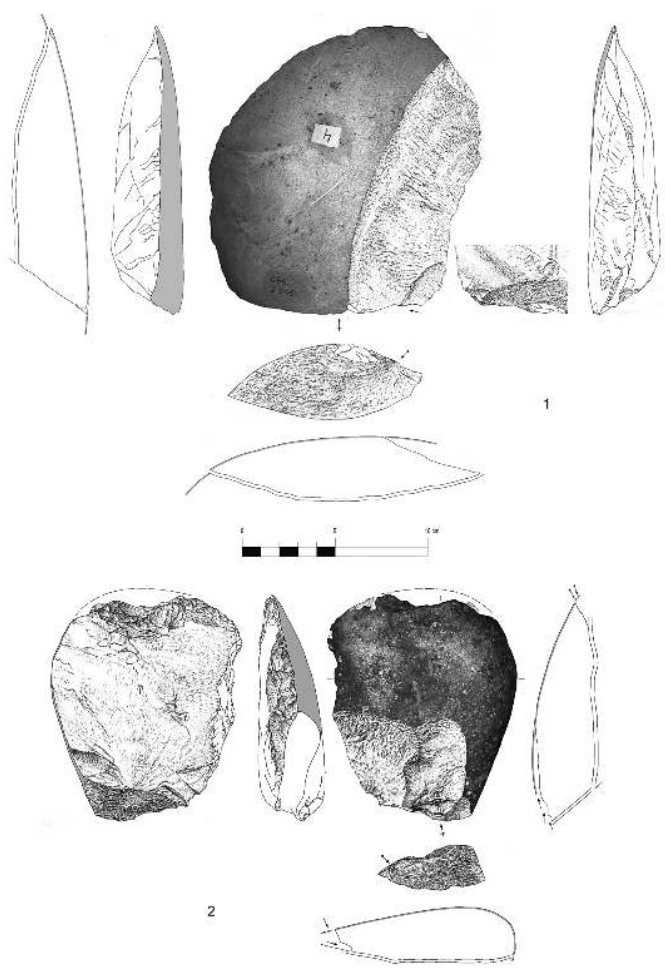


Figure 10 - Large flakes with cortical biseau showing a bilateral preparation, hearth $\mathrm{k}$ of the Observatoire Cave (drawings by M. Grenet).
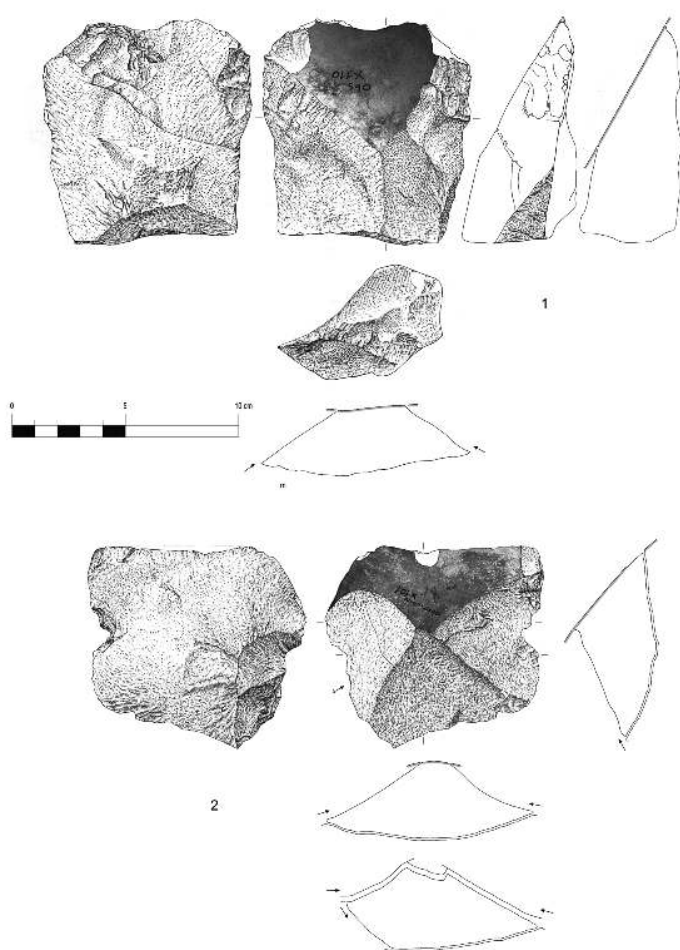

Figure 11 - Large flakes with cortical biseau showing a bilateral $\left(n^{\circ} 1\right)$ an unilateral $\left(n^{\circ} 2\right)$ preparation, hearth $\mathrm{k}$ of the Observatoire Cave (drawings by $\mathrm{M}$. Grenet).
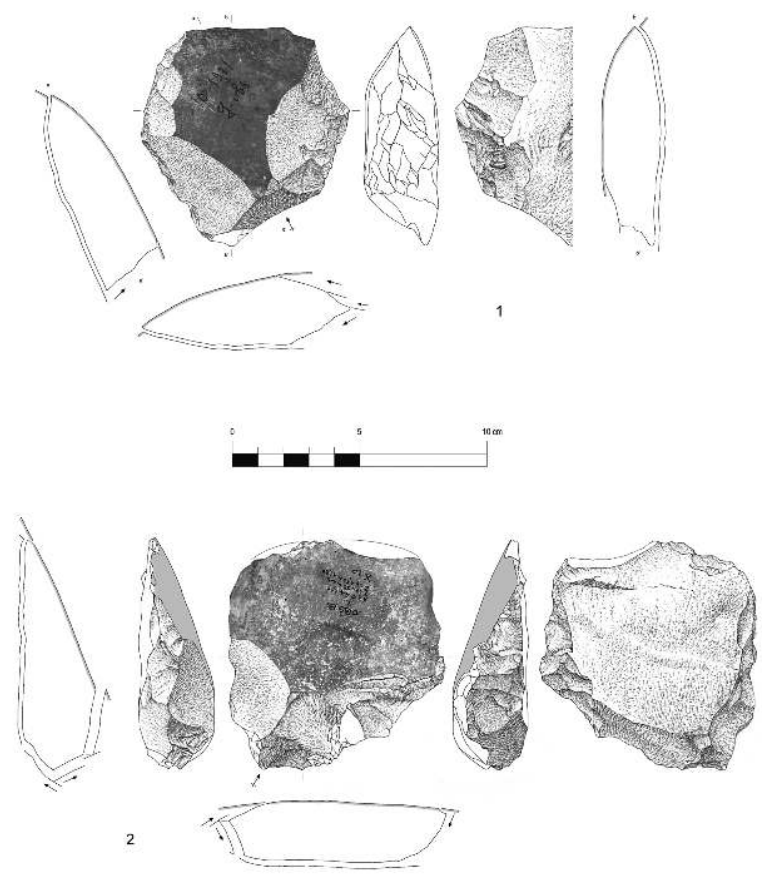
Figure 12 - Large flakes with cortical biseau showing a bilateral preparation, hearth $\mathrm{k}$ of the Observatoire Cave (drawings by M. Grenet).
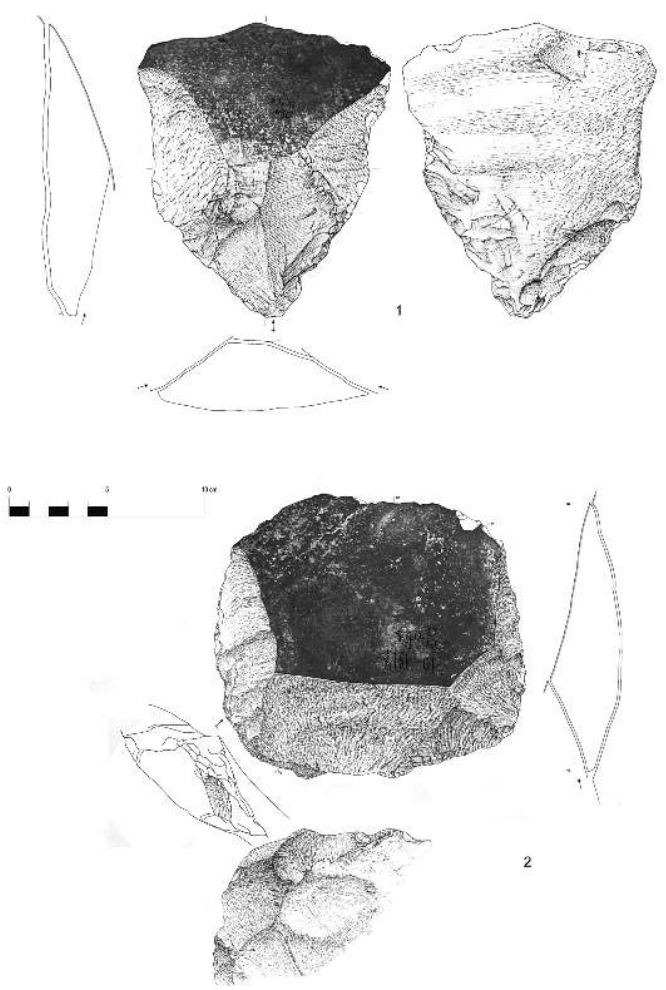

Figure 13 - Large flake with a prepared biseau $\left(n^{\circ} 1\right)$ and large flake with cortical biseau showing a bilateral preparation $\left(n^{\circ} 2\right)$ from the hearth " $k$ " of the Observatoire Cave (drawings by M. Grenet).
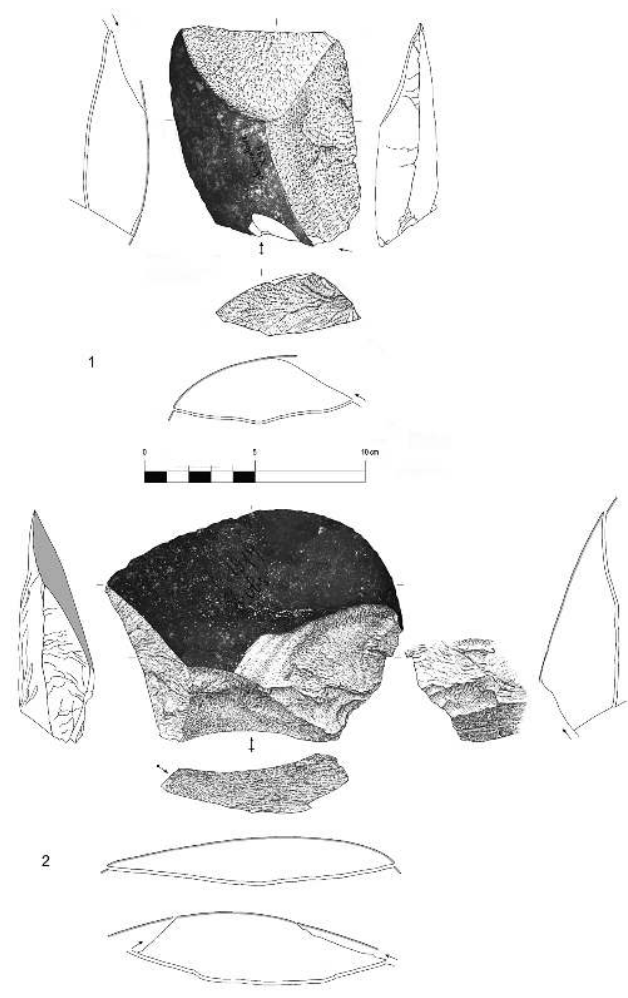
Figure 14 - Flakes with a prepared biseau from the hearth $\mathrm{k}$ of the Observatoire Cave (drawings by M. Grenet).

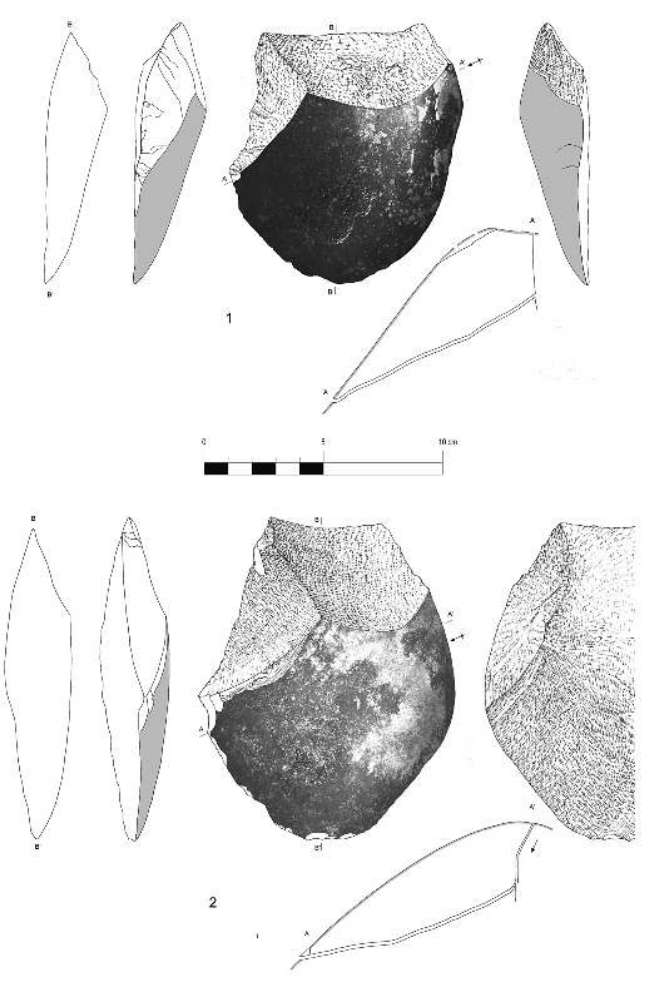

Figure 15 - Entames from the hearth $\mathrm{k}$ of the Observatoire Cave (drawings by M. Grenet).

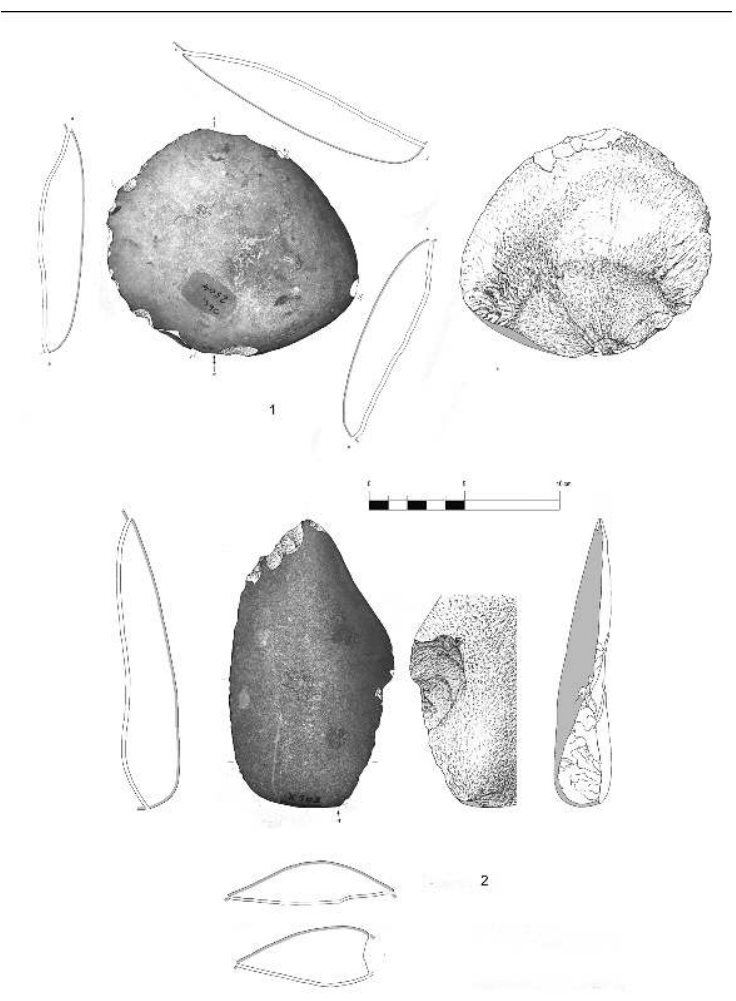


Figure 16 - Entame and flake with a cortical back from the hearth $k$ of the Observatoire Cave (drawings by M. Grenet).

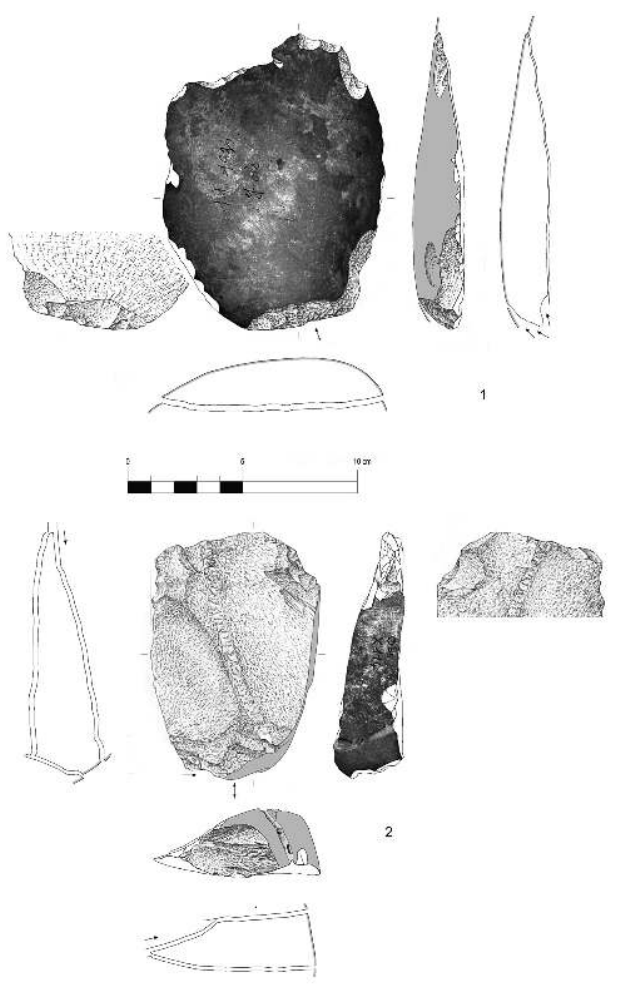

Figure 17 - Flakes with a back of debitage from the hearth $\mathrm{k}$ of the Observatoire Cave (drawings by M. Grenet).
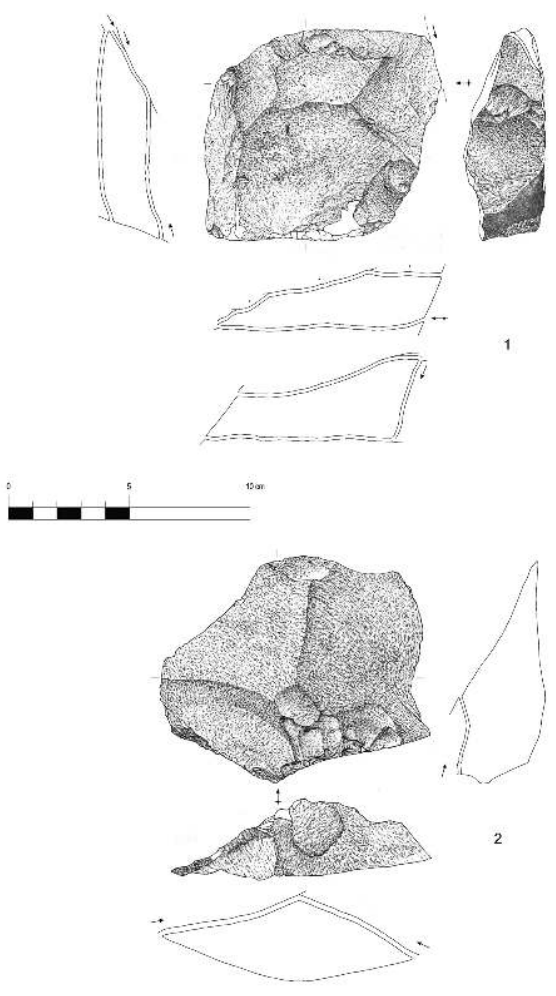
Figure 18 - Techno-functional characteristics of the large flakes with a cortical biseau from the hearth $\mathrm{k}$ of the Observatoire Cave.
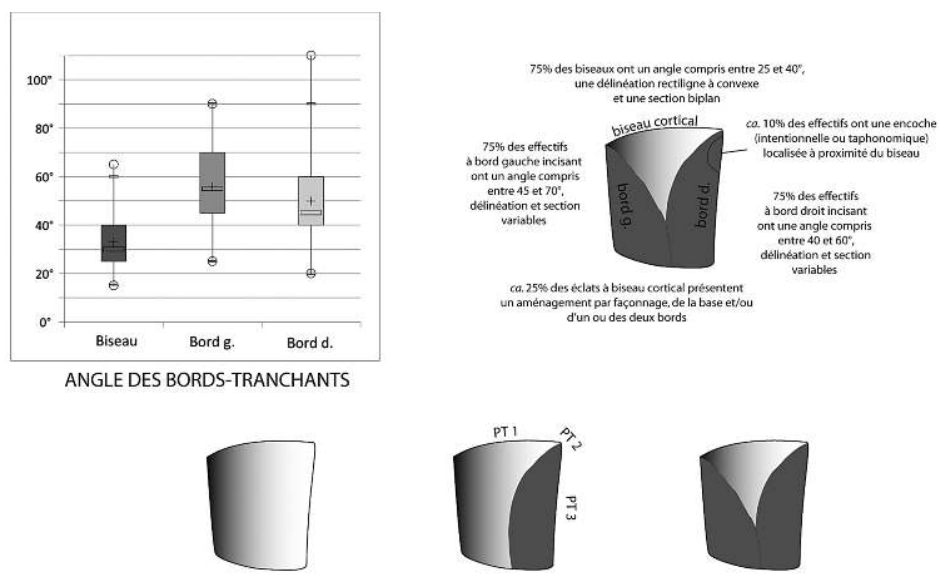

$29 \%$ des éclats a biseau cortical
ont un tranchant exclusivement dista

62\% des éclats à biseau cortical presentent un tranchant adjace

996 des éclats à biseau cortical
asentent un tranchant périphérique
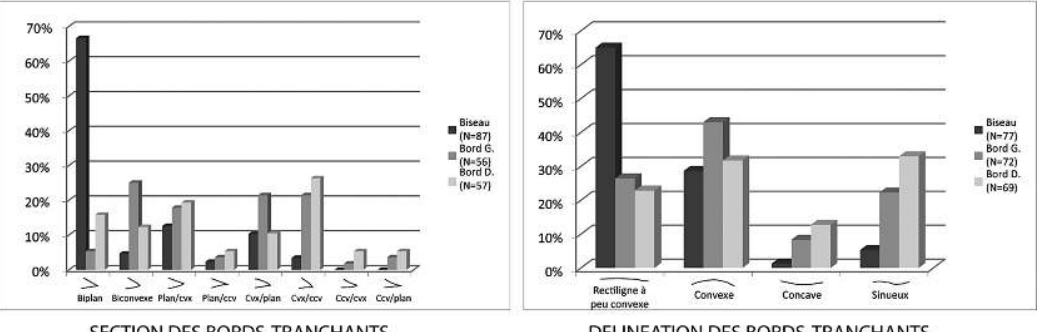

SECTION DES BORDS-TRANCHANTS

DELINEATION DES BORDS-TRANCHANTS

Figure 19 - Directions of the blow for the large flakes with cortical biseau from the hearth $\mathrm{k}$ of the Observatoire Cave.
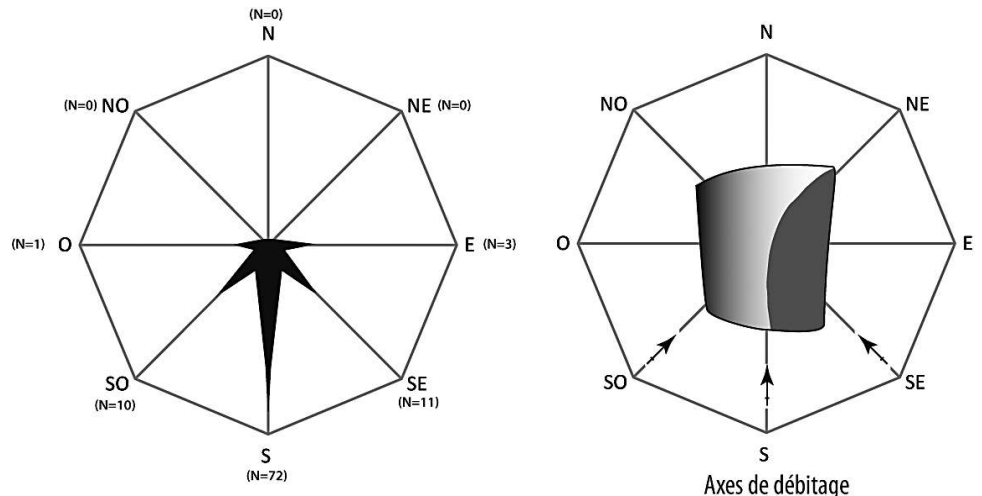
Figure 20 - Planarity of the cortical surfaces exploited at the Observatoire Cave. The calculation of the planarity is based on the measure of 4 equidistant points taken in the axis of debitage of the large flakes. The data appearing on the spherometer (given in dioptries, image on the left) indicate a curvature radius ( $R$ ). These data, expressed on a boxplot (on the right), express a regular diminution of the curvature radius; which tends to be almost a flat surface on the distal part.
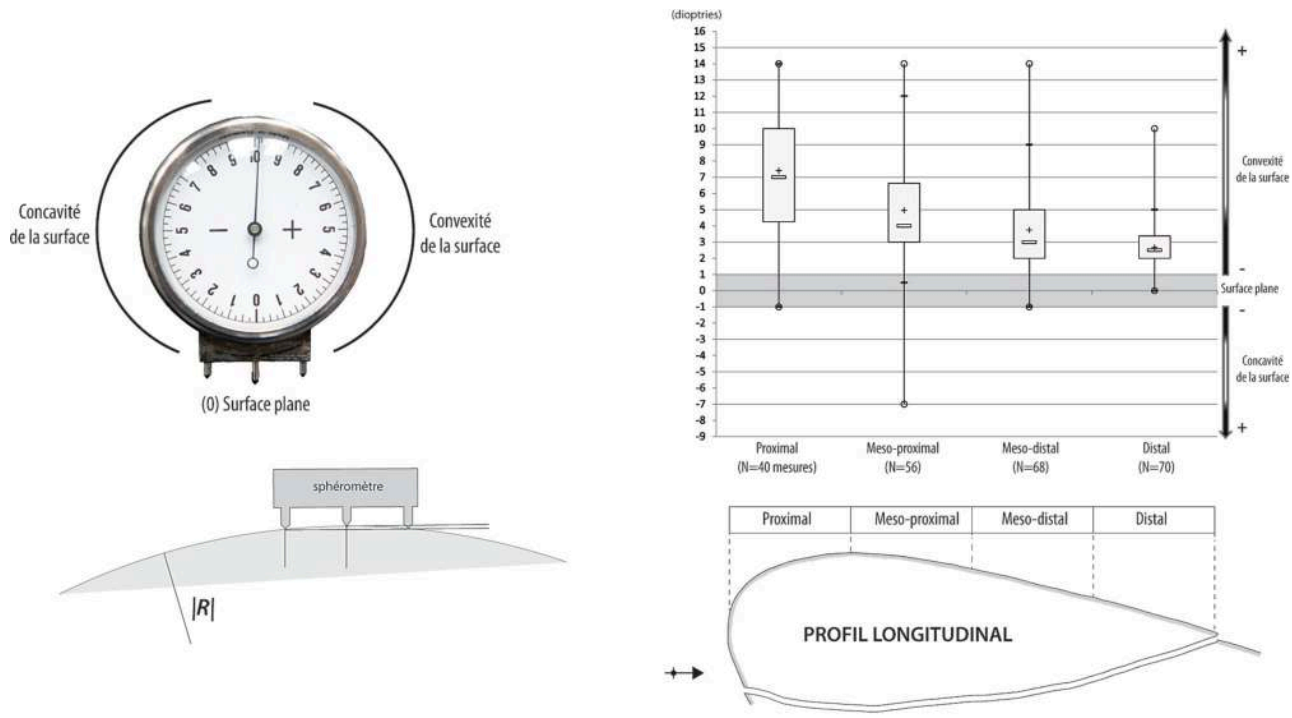

Figure 21 - Butts types and angles of the large flakes from the hearth $\mathrm{k}$ of the Observatoire Cave.
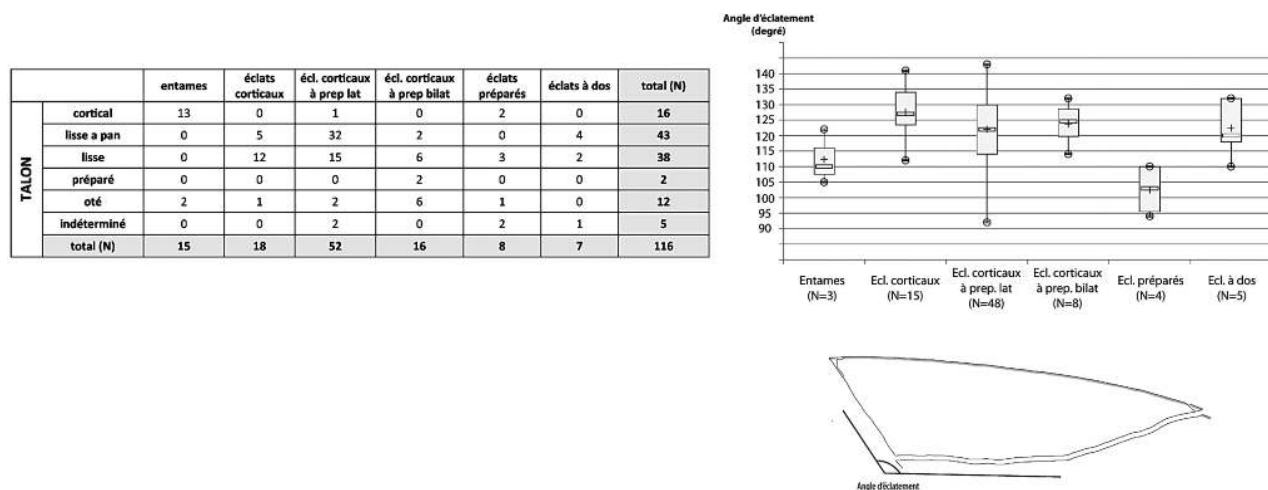
Figure 22 - General observations (raw materials, metrical data, morphologies, presence or absence of natural or functional marks on the surface) on the cobbles from the hearth $k$ of the Observatoire Cave.
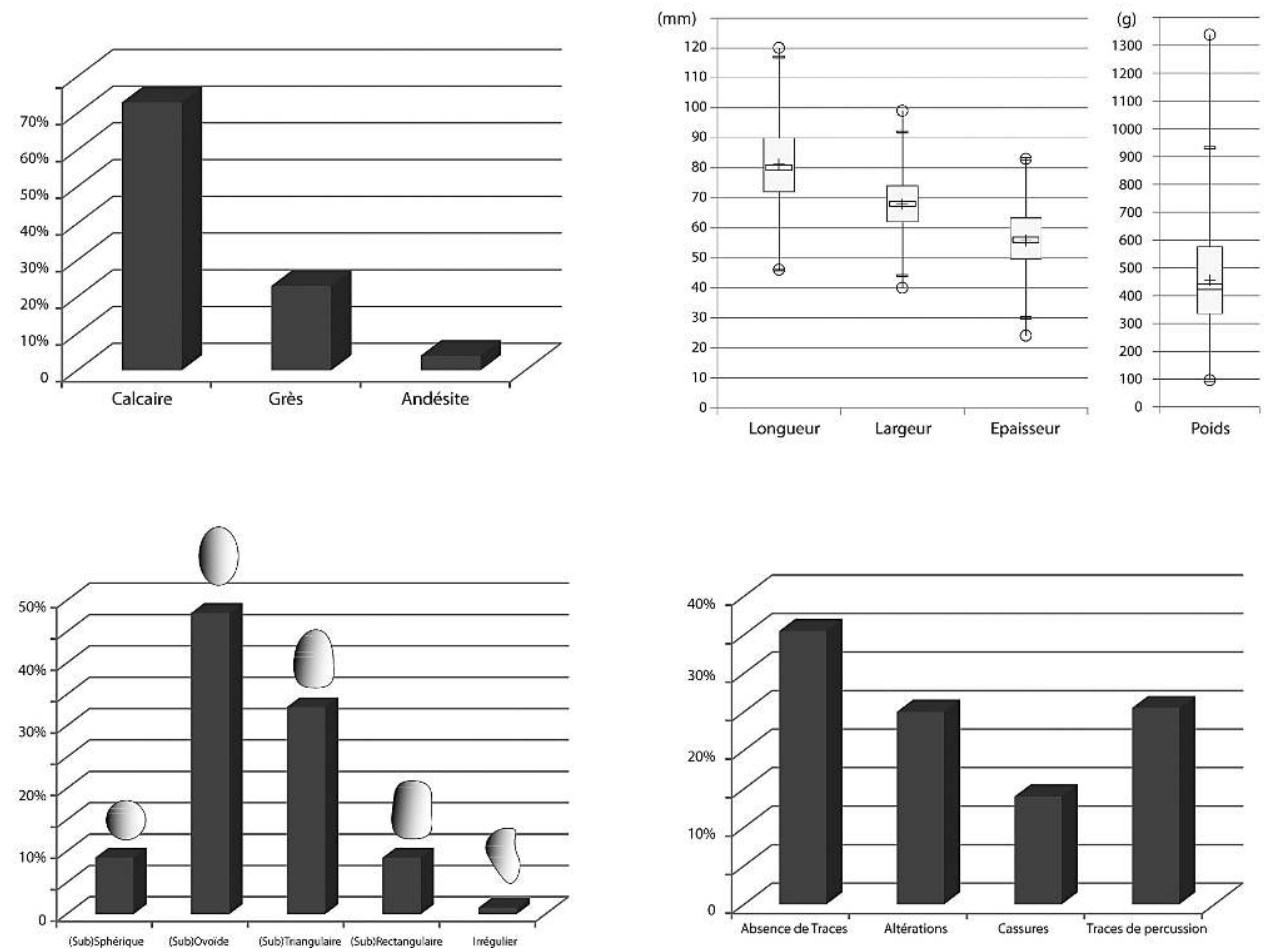

Figure 23 - Examples of cobbles from the hearth $k$ of the Observatoire Cave $\left(n^{\circ} 1-3,6\right.$ : sandstone, $n^{\circ} 4-5,8-9$ : limestone, $n^{\circ} 7$ : andesite $; n^{\circ} 1-3,5$ : cobble with scars of a use in percussion ; $n^{\circ} 6-7$ : cobbles with marks of an anvil percussion ; $n^{\circ} 4$ : cobble with one intentional removal ; $n^{\circ} 8-9$ : incidental flakes from a percussion) (clichés Michel Dagnino, DAO F. Burle, G. Porraz).

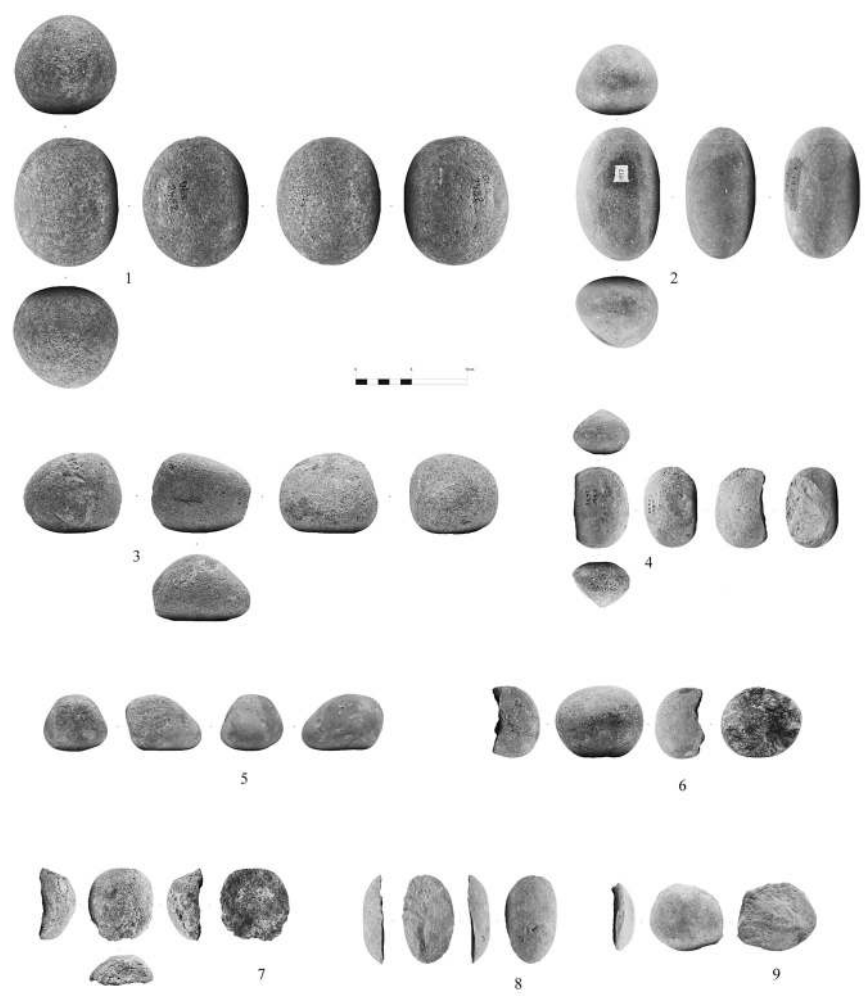




\section{The handaxe with reserved base} large flakes, selected natural pebbles and a single handaxe. The access to the technical know-how of these populations is therefore based primarily on the large flake collection, which shows a strong homogeneity. The synthesis that we propose of the debitage of large flakes with cortical bevel, or Observatory debitage (fig. 25), is an interpretation based on a series of mental re-fittings (Pelegrin 1995) done from our inventory of finished products $(\mathrm{N}=132)$.

knappers of the Observatory cave repeated identically a series of well controlled gestures and operations, particularly suited to the worked material, which were aimed at the production of flakes with a transversal cutting edge, large sized and high in mass. The design of the debitage involved the production of a single predetermined flake per block. Only part of the volume was therefore used by the knappers, without recurrence, without technical solution applied to reconfigure identically the volume of the core. As part of this short operating sequence production, we recognize two critical steps: 1) the design or initialization phase of the useful volume; 2 ) the flake removal or task execution phases. 

the angle of $90^{\circ}$ radius to the future axis of the debitage of the desired product. This removal is strictly predetermining, its objective being to rebalance the natural transverse convexities of the selected pebble. If necessary, a second flake (E1'), opposite the first, was detached, similarly oriented in an angle of a $90^{\circ}$ radius relative to the future axis of debitage of the desired product. The choice whether or not to remove a second predetermining flake was then established according to the natural convexity offered by the pebble. The available data suggest an E1 operation that was slightly offcentre on the operating surface (taking advantage of the natural convexities) and an E1' operation that was meanwhile focused more on the surface. The prior establishment of a striking platform for the proper control of the E1 / E1' removals does not seem systematic to us. The flake fig. 15, No. 1 would be potentially an example of an E1 type of removal, characterized by the presence of asymmetrical transversal natural convexities.

51 After configuring the debitage surface, the intention was to prepare the striking surface area of the future desired flake. The aim was to set up a much angled striking platform surface with regard to the debitage surface. The operation was to detach a flake (E2) oblique or perpendicular to the axis of the debitage surface, while taking advantage of the obliquity of the E1 or E1' removal negatives, or of the obliquity of the natural surface of the pebble. The flake fig. $15 \mathrm{~N}^{\circ} 2$ potentially represents an E2 type of removal; in this case, it is the distribution of the natural convexities centred and diffuse throughout the longitudinal axis of the flake that suggest a removal in the thickness of the hemispherical pebble.

52 The technical criteria for the predetermination of the transverse cutting edge were then brought together to detach the predetermined flake (E3). Theoretically, the operation could be repeated a second time, depending on the size and configuration of the debitage surface, and after re-preparing the surface of the striking platform. However obtaining a second predetermined flake (E3') appears to us, if not opportunistic, at least subject to variables that do not appear to have been deliberately controlled by the knappers.

53 We emphasize here the importance of predetermination (Tixier et al. 1980; Boëda 1994; Texier and Roche 1995; Mourre 2006). This concept is based on a difference between what a knapper prefigures (he knows the rules of mechanical rupture, he anticipates the result of his gesture of percussion) and what he predetermines (he changes the block geometry and by a series of gestures, gets what he planned). In our case, even if the desired flake is closer to the natural characteristics of the selected pebble, its bevel does not pre-exist the natural shape of the pebble and is therefore predetermined. A series of predetermining removals creates the desired tool. 

operation repeated on another pebble. Alternatively, some of these cores were used in compliance with new technical criteria, emphasizing a greater flexibility of the knapping objectives. The original intention seems to have been to continue producing large flakes, whether backed, whether prepared. In the latter case, some examples show that a succession of crossed removals were done before removing an invasive flake, the flaking angle then stressing a change in the geometry of the knapped volume (fig. 21). Although predetermination is at the heart of the debitage of the Observatory, we do not recognize the principles of a Levallois production (Boëda 1994), which differs in its geometry, its intentions and its principle of recurrence. also determined by the techniques and quality of the percussive gestures, essential to the good control of predetermining and predetermined characteristics. If we recognize the strict use of the stone and of percussion, the knapping stigmas seem to account for gestures and percussive masses combined differently depending on the objectives and / or controllability of the core (see Mourre and Colonge 2010). We recognize at least two percussion techniques, combining cores in mobile station and dormant station:

- Some entames (fig 15, $\mathrm{N}^{\circ} 1$; fig 16, No. 1) show that the opening of the pebble could be done by percussion of the block on a fixed hammer. This determination is based on the flatness of the ventral face, marked by a lack of bulb bulge and a pronounced crushing at the level of the percussion cone;

- After the opening of the block, the main technique used was direct hard hammer percussion, with a stable hold of the core. Given the large volumes operated, we offer an immobilization system of the core on the ground, facilitating an inward inner percussion what we call "muffled" (gesture and type of immobilisation). We join here the assumption made by V. Mourre and D. Colonge (2010), the only solution allowing good accuracy in the percussion gesture. The percussion is crucial since it will ensure the predetermined nature of the ventral face of the bevel (for E3 type of flakes).

This chaine opératoire aimed to produce standardized and predetermined flakes in their transformative parts. These intentions are indirectly read in the nature of the shaping and manufacturing operations, as the predetermined transformative part always remained raw after knapping. The transformative part was a fine bevel with an angle between $25^{\circ}$ and $40^{\circ}$, rectilinear to slightly convex, straight and biplane in section. If the absence of a detailed study of micro traces of use is problematic for a specific discourse on the issue of the modes of use, the description of the technofunctional characteristics and of the macrotraces nevertheless allow us a first development. We are considering a diversified use, involving incising actions as well as percussive ones with localised transformative contacts located on the cutting edge (PT1) or its protuberances (PT2) (fig. 18). We are considering a flat functioning of the tool, or on the side, for a manual prehension positioning the transformative axis in the prehension axis, or perpendicular to it. We therefore favour the hypothesis of a rather flexible tool in its functions and its working.

In addition, if the debitage was organized around a specific techno-functional purpose, the desired tool automatically seemed to integrate non-predetermined complementary characteristics, non-standardized, yet expected, that we call secondary. Indeed the adjacent cutting edges to the bevel represent a functional solution, which in some cases appears to have been exploited by the users (PT3) (fig. 18). 
58 The preferential debitage with a single sequence at the Observatory covers the principles of a type D debitage (Boëda 2013), in which only the useful volumes are worked. The standardization and the predetermination of the large flakes with cortical bevel, for some of them obtained by a series of 3 strikes only, show a high degree of conception of the debitage (Roche and Texier 1991).

Figure 24 - Biface with an unmodified cortical base from the hearth $k$ of the Observatoire Cave.
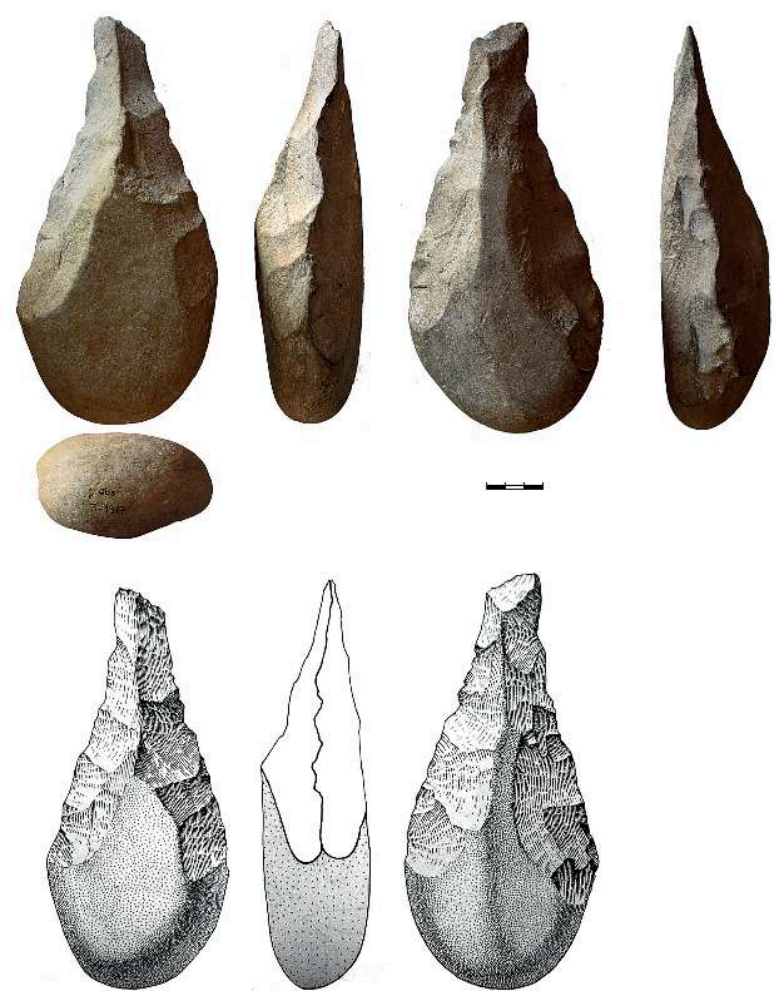
Figure 25 - Schematic drawing synthesizing the system of debitage of the large flakes with a cortical biseau, or debitage of the « Observatoire » type (drawing by M. Grenet). After the production of the predetermined flake (E3), this débitage could go on to produce naturally backed flakes or prepared flakes. However the study of the lithic collection shows us that this continuation in the production was not systematic and even so, was then associated with a change in the objectives of the production.

Séquences opératoires du débitage de l'Observatoire

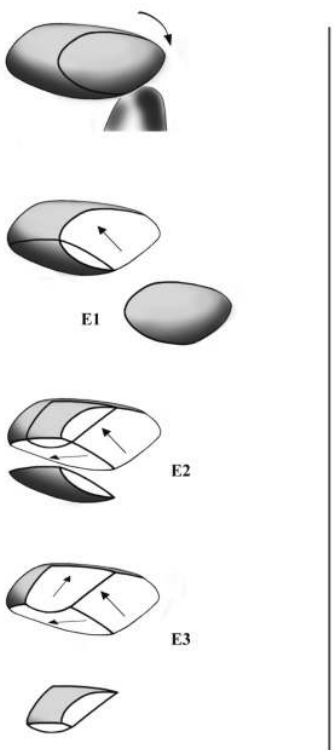

Modalité à préparation unilatérale

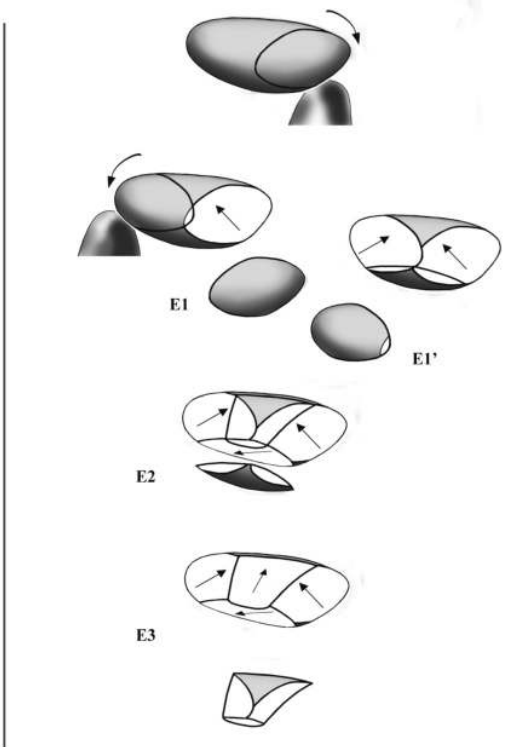

Modalité à préparation bilatérale

\section{The first human settlements in the Observatory cave}

In the Ligurian-Provençal arc, the earliest known human occupations would be those of the Vallonnet cave (Lumley 1976). However the most comprehensive and reliable data we have today are those of the open air site of Terra Amata, excavated in the years 1960s. The site, which includes three archaeological levels, indicates human settlements on the Mediterranean coast, the earliest dating from the MIS 11 (Falguères, Yokoyama, Quaegebeur 1988; Lumley et al. 2009). Following this, the oldest regional sites dated today are from the end of stage 7 and stage 6 with the human occupations of the Lazaret cave in Nice (Michel et al. 2009, Lumley et al. 2008) and of the Prince cave in Ventimiglia (Barral and Simone 1967; Simone 2008). Therefore, one needs to exit the Ligurian-Provençal space to widen the list of early Palaeolithic site, including notably the first human occupations of Baume Bonne, which could date back to the MIS 10 (Gagnepain and Gaillard 2005). The archaeological record is more consistent when it opens to the Languedoc region and the Rhone Valley, where many studies have shown the antiquity of human settlements in this area. We will mention in particular the Tautavel cave (stages 14 for the oldest occupations, Falguères et al. 2004), the Aldene cave (stage 11, stage 5; Barral and Simone 1972; Falguères et al. 1991), or that of Orgnac 3 (stage 9 and 8; Moncel et al. 2011; Michel et al. 2013). On the Italian side, few ancient sites within easy reach of the Observatory have previously been reported (Palma di Cesnola 2001; Grifoni and Tozzi 2006). 

stage 7, with a U / Th date $>230,000$ years obtained directly from the floor III. The currently available data are very fragmentary and limit opportunities to push the comparisons with other neighbouring sub-contemporary occupations. Similarly, the large flakes of hearth $\mathrm{k}$ have no regional equivalent from a technological viewpoint. The settlements of the Lazaret cave and the Prince cave, more recent than those of the Observatory, associate the presence of bifacial pieces and flakes, mostly on flint, some retouched as scrapers. A slightly closer proximity can be found with the collections of Terra Amata (Lumley et al. 1976), marked by the use of limestone pebbles and the presence of some cleavers $(n=11$, in Villa 1983). However, the techno-typological comparisons end there. In Terra Amata, the use of the limestone pebbles mainly takes the form of "chopper-core", the few cleavers are little characteristic and mainly made on split pebbles ("Terra Amata" type in Villa 1983) and the lithic industry, called nonClactonian includes a flint flake production, some of which are retouched. Thus the lithic industry of hearth $\mathrm{k}$ of the Observatory cave is individualized from a regional perspective, encouraging us to think critically about the meaning of this assemblage. hindering our understanding of the lithic assemblage formation dynamics. But for our case study, its strong homogeneity challenges us and must be discussed. The assemblage is composed of large flakes, of hand-carried pebbles and of one handaxe with reserved base. However the uniqueness of the latter and its stratigraphic positioning (outside the maximum concentration zone of larger flakes) are inviting us to put into perspective the chronocultural significance of this handaxe and its role within the techno-economic background of the people of the Observatory. Similarly, we are excluding the hypothesis of a sorting by the excavators that would have been done exclusively in favour of the large sized limestone elements. To support our position, 1) we note that the (small) flakes in flint and quartzite from hearths $\mathrm{h}$ and e have been collected (as well as the flakes from the Middle Palaeolithic and the blades from the Upper Palaeolithic), 2) we recall that the excavation of de Villeneuve's waste has not led to a large collection of small flakes (and also no core or large limestone pebbles were found). Even if there is a loss of information that is final and if the nature of this loss escapes us, however, we believe that the techno-typological and petrographic homogeneity of hearth $\mathrm{k}$ of the Observatory cave constitutes an element that characterizes the industry.

The rather large inventory of large flakes and hand-carried pebbles testifies in favour of multiple episodes of introduction of tools and, by extension, of several phases of settlement. Schematically and simplistically, we can assume a techno-economical combination (the "toolkit") combining large flakes and hand-carried pebbles. For an idea, the ratio in the Observatory cave is 1 large flake for 1 hand-carried pebble. The nature of the tools allows partitioning the registers of activity, with on the one hand the large incising flakes potentially used in fixed and mobile percussion, and on the other the blunt pebbles used in percussion and/or crushing.

The Observatory cave is in a steep environment, overlooking the sea or its horizon. From the point of view of the subdivision of the chaines opératoires and the insertion of the cave in a territory, we are observing a pattern that repeats itself. Within a radius we can reasonably estimate to $5 \mathrm{~km}$ around the Observatory site, the knappers went and selected large limestone pebbles they knapped, leaving behind the debitage waste 
and the products seen as non-conform. The selected large flakes were then transported and used in the Observatory cave or its immediate environment, and then were left in the Observatory. The lack of flakes with accidents and of cores supports this hypothesis of technical operations that were well segmented in space, with the Observatory cave as a receptor site. It is likely that knapping activities were also held at the site, such as the re-working of some large flakes by shaping or debitage of some hand-carried pebbles, but the elements available today do not really allow appreciating their natures. The techno-economical reading of the chaine opératoire of the hand-carried pebbles is summed up to its simplest expression, i.e. a selection on the coastal strip, a use/transport and finally abandoning at the Observatory cave. Thus, just like the chaînes opératoires, the nature of the techno-economical behaviours is an original element that singles the first human occupation of this site.

In other contexts, these techno- economical behaviours would be interpreted as signs of specialized occupations, based on the introduction of finished products involving anticipation of needs over time (Kuhn 1995). Therefore, the specifics of the lithic assemblage of the Observatory would reflect a variant of a functional nature, for which the "residential" signature today would be relatively vague from an archaeological point of view. We are there at the limit of the interpretation, which would require to feed from contextual data and comparisons with other regional sites.

However, regardless of this functional register that aims to assess the observed variability angle, we must concern ourselves with proper technical systems in order to explain the nature of the adopted techno-economical behaviours. Indeed, we must consider the binding nature of the macrolithic phenomenon in the framework of the procurement strategies and renewing of the toolkit the Early Palaeolithic.

Studies available today punctually highlight the transportation of blocks from their collection sites to a processing and abandonment location, but these movements only occur over short distances and in the context of open-air occupations (i.e. FéblotAugustins 1997; Lhomme 2007). From the literature (Féblot-Augustins 1997; Turq 2000; Santonja and Villa 2006; Gregory et al. 2007; Cauche 2012), we will retain two main points, intrinsically linked: firstly the existence of differences between open-air occupations (usually on or near the sources of raw materials) and those in cave-shelter; secondly, movements of macro tools limited in space, only rarely exceeding the limit of $10 \mathrm{~km}$. Thus the supposed specialization of the lithic corpus of the Observatory would not only reflect a functional adaptation, but equally, or even firstly, a technoeconomical adaptation conditioned by the macrolithic nature of its toolkit. In this perspective, the low transportation distances observed at the Observatory cave should not be interpreted directly as a low mobility of humans (in amplitude), but must be interpreted in the light of a technical system imposing the mobility of the toolkit and contracting the techno-economical organization of activities in space.

\section{The soucoupes from the Observatory. from the distant arrival to the local appearance}

67 The industry of the Observatory cave, its large flakes in particular, find to date only very distant equivalents. However, we must return to the determinism and adaptations that might explain the uniqueness of this industry in its regional context. If the nature of the archaeological and sedimentary records can be the main cause, we would ask 
ourselves here more specifically the question of macrolithism and its relationship to the materials and worked volumes. This reflection, frequently raised in the study of large flakes (Villa 1983; Santonja 1996; Sharon 2008), leads us to broaden our scope of comparison and to position ourselves on the issue of diffusions and convergences.

The question of the presence of the large flakes, their very existence, is connected to the definition of this category, not fundamentally technological but primarily dimensional. Thus the large flakes, by default and for example, have never been knapped on the small flint pebbles of the Lazio beaches. This raises the question of the meaning of the macrolithic characteristic from the viewpoint of technical traditions and know-hows.

The Ligurian-Provencal arc has the advantage of partitioning in different geological areas (Porraz and Negrino 2008; Tomasso et al. submitted), that motivated different behaviours and adaptations according to the technical traditions and nature of the mineral resources. On the issue of the availability of knappable rock, these are present in large quantities and large volume all along the coastline, from the Esterel Permian massif to the west and its large effusions of Rhyolite, to the Flysch with Helminthoida in the East with its microquartzite blocks and pebbles. Between these two large groups, the limestone pebbles of the type used at the observatory dominate. They are accessible in conglomerates, in coastal bars or old river terraces (having moved the mentioned conglomerates). In our study area, the question of the existence of a macrolithic tradition does not suffer from a lithological determinism.

However, given the specific characteristics we identified in the working of the pebbles at the Observatory (adaptation and use of the natural volumes), we can expect differences in the operating schemes according to the knapped morphologies. The observatory's knappers had adopted an active approach favouring a morphology (on part of the volume only) that foreshadowed the future tool. Thus the formula of the knappers from the Observatory exists, and can only exist, in the context of using weakly bulging natural surfaces. However, if the morphologies may set ways, they do not influence in any way the techno-functional objective achieved in the desired tool.

The large flakes with cortical bevel from the Observatory define a population that encompasses that of cleavers. This tool on flake is defined by the presence of a wide cutting edge "prepared" at one end, according to abbot H. Breuil's words (1924). The characteristic type of the cleaver combines two technical steps that are 1) the preparation of the cutting edge by the removal of a predetermining flake, 2) the shaping of the edges and base to result in the finished tool (Mourre 2003 for a synthesis of works on this topic). Our inventory at the Observatory cave therefore covers the structure of the cleaver from a techno-functional point of view, but moves away from it on a strict point of view of the chaines opératoires. While some examples show a bevel predetermined by the negative from a removal, others are shaped on their edges, but these two operations are very rarely associated on the same specimen and, in general, are not the technical standard at the Observatory Cave.

The standard at the Observatory is that of a non or little transformed flake, with a cortical bevel. We then find a comparison with what has been called proto-cleaver (or cleaver 0) by J. Tixier (1956), i.e. tools characterized by the absence of predetermining removal at the cutting edge. However, the shaping of the non transformative parts is presented as a defining criterion: 
"They are sharp pebble fragments with terminal cutting edge obtained by the meeting of the tearing face and the natural surface of the pebble, furthermore with marginal retouches. These retouches start whether from the flat face, whether from the upper face and are sometimes alternate. The flake was hit directly on the natural surface of the pebble or, less often, on a prepared striking platform "(Tixier 1956 - 916 p.).

A close characterization of the proto-cleaver is offered J. Heinzelein de Braucourt (1962 - p. 44):

"The simplest model of cleaver where the cutting edge is obtained by the intersection of the ventral side of a large flake with the cortex or the natural surface of the pebble or of a block. The side edges are accommodated by marginal retouches more or less developed for gripping. Could also be called Ternifine Cleaver.»

If a number of flakes with cortical bevel from the Observatory cover the definition of the Cleaver 0, many moves away from it by the lack of shaping. In addition, when shaping was done, it has generally been confined to limited portions of the blanks. shaping was well integrated in the approach of the knappers of the observatory, but was not a structuring operation in the manufacture of the tool.

The differences of definition that we can note between the flakes with cortical bevel from the Observatory and the cleavers or proto-cleavers in the literature show the history of research that saw the technological criteria dominate the debate about the definition of the toolkit, while today there is a rebalancing towards techno-functional descriptive approaches. In this perspective, we are joining with the conclusions of $\mathrm{V}$. Mourre (2003 - p. 250), who places the bevel and its predetermination (i.e. its intentional nature) alone at the heart of the definition of the cleaver.

"A cleaver is a tool on flake with a raw cutting edge formed by the intersection of the lower side of the blank with an upper side corresponding, according to the cases, to one or more previous negatives, to a positive, to a positive and one or several negatives or even to a cortical, neocortical or natural surface. Therefore, the predetermination of the cutting edge is not an intrinsic feature of the cleaver at the scale of the isolated object; however, it can be seen as such, in our view, across a series since there is no representative series consisting only of cleavers with nonpredetermined cutting edge. "

The search for regional technical equivalents to the large flakes the Observatory should be opened more broadly to all the series with cleavers, which, we have reported it, however, are virtually absent from the Ligurian-Provençal arc. Indeed, only a few specimens are known today on split pebble in the site of Terra Amata. This relative scarcity of the cleaver tool in the early Palaeolithic also seems to characterize the whole of Western Europe (Mourre 2003; Santonja and Villa 2006; Nicoud 2013a). Between isotopic stages 16 and 9, the cleaver is thus absent from the "Acheulean" European sites in stratigraphic context that could be dated (Nicoud 2010, 2013a). The cleaver really seems to develop only from isotopic stages 9 and 8, especially in Spain and in the south west of France (Mourre 2003; Sharon 2007; Mourre and Colonges 2010). But it is precisely in the latter geographical area that the technical phenomenon of the large flakes or "Large Flakes Industries" (Sharon, 2007, 2011) was limited in Europe .

The series of large flakes from the Iberian Peninsula and the south west of France, among which we can mention for example the sites of El Sartalejo and Pinedo, all match open-air settlements, positioned on ancient terraces yielding abundant raw materials available as pebbles. The selected and knapped rocks are mainly represented 
by quartzite, sandstone, some volcanic rocks and rarely limestone. No absolute age is available but geomorphological studies tend to position these technical traditions in the isotopic stages 8 and 7. The available studies indicate series largely dominated by large flakes, very predominantly cortical, reflecting short operating sequences for very limited shaping phases of the volumes. Now these series are also distinguished by the presence of type 0 cleavers. This technical tradition of the Iberian Peninsula and its margins would therefore represent a distant equivalent to our large flakes in the Observatory.

These "Iberian" series would show great similarities with those from North Africa. These similarities are based on the recognition of the method called "entame debitage" (Sharon, 2007, 2011). This is a relatively simple debitage marked by a strong investment in the selection of the blocks, oriented toward pebbles -in quartzite for most- flat in morphology. The entames, sometimes removed after opening a striking platform, are then used as blanks for the shaping of handaxes and type 0 cleavers. These technotypological proximities, noted as early as the second half of the twentieth century, were used to develop of a diffusion model of an Acheulean from North Africa toward Spain via the Strait of Gibraltar (Bordes 1966; Alimen 1975; Tavoso 1986; Otte 1996; Sharon 2011).

In this general context, the large flakes of the Observatory could mark a new extension point, beyond the previously known boundaries of this technical phenomenon. At this stage of our study, our question is less about the issue of the migration route itself (the Strait of Gibraltar) than on the validity of the diffusion hypothesis (technical descent). What convergence degree has the collection from the Observatory with the documented series of the Iberian Peninsula and North Africa?

The search for large-sized flakes, the preferential exploitation of flattened natural surfaces, the shortness of the operating sequences and subsequently the importance of the cortical flakes and the presence of the cleaver tool are the elements that allow grouping these industries. Nevertheless, the collection of the Observatory is individualized under several angles of analysis. Firstly, in the Observatory cave, we do not recognize the principles of the entame debitage that results in an absence of predetermination and in debitage axes variously positioned relative to those of the future tool. In addition, other chaînes opératoires (bifacial shaping and Kombewa flake debitage) are coexisting with the entame debitage, which is not the case at the observatory. Similarly, cleavers 0 only account for a small number of specimens at the Observatory cave. Finally, let's remember that most rocks knapped in the Iberian Peninsula and its margins are hard rocks, while only soft rocks (used and available) are found at the Observatory cave. The differences that individualise properly the series of the Observatory would thus be hiding behind a phenomenon of first degree of convergence.

81 What can be the origin of the soucoupes of the Observatory? What means do we have and on what degree of convergence can we base our reflection? To date, in the absence of adequate documentation, we reject the hypothesis of a gradual transformation on the basis of a local substrate. We favour two lines of reflection: diffusion and local innovation.

Diffusion is often the preferred hypothesis in the literature: an innovation has a starting point (generally not known for the Palaeolithic or, at best, assumed) and it diffuses in the form of ideas (interactions) or goods (peopling). Questioning the reality 
of this diffusion is then based on the use of contextual data (i.e. uncertain or inconsistent dates) and/or the adoption of a theoretical discourse on the evolutionary history of techniques (Boëda 2013; Simondon 1958). In the latter case, the tool has an evolutionary line of its own, certainly influenced by the external environment, but nevertheless determined by its operating structure and the initial nature of the requirement to which it is a response. This line results in evolutionary stages that head towards a realization of the tool, which somehow specializes in its work and role; analysis and large-scale comparisons are then used to develop arguments on this subject (i.e. Chevrier 2012a)

The cleaver is invariable in its transformative part, it presents a unique concept, highlighting the difficulties of thinking its original stages. This is a massive tool, macrolithic, organized around the presence of a raw transversal edge, straight to convex, biplane in section for angles generally between 30 and $60^{\circ}$ (Mourre 2003). We would be here facing a functional universal, i.e. a biplane cutting edge with a knapping angle of $\pm 40^{\circ}$, which "corresponds to weak cutting edges but of high durability and with the ability to perform hard work on different materials" ( Geneste and Plisson 1996 - p. 356). This universal functional of the cleaver leads therefore to think its variability (and its evolutionary potential) under two main angles: 1) the degree of predetermination of its transformative part 2) the nature of the secondary characteristics or non transformative parts. In this research of a history of techniques, J. Tixier (1956) considers the possibility of a chronological succession behind his typotechnological suite of cleavers, those of lower degree of predetermination and development (type 0 ) potentially constituting the first form of this tool.

We have seen that the flakes with cortical bevel from the Observatory cover well the concept of the cleaver tool. Nevertheless, more flexibility emerges from the assemblage of the Observatory supported by the low frequency and intensity of transformation of the non-transformative parts. In some cases, moreover, these flakes with cortical bevel seem to have integrated several transformative parts (see above). Others, although from the same chaîne opératoire, move away from the standard type by the presence of more oblique cutting edges compared to the debitage axis and more convex delineations (fig. 9, No. 1). If the fashioning consecrates a specialization of the cleaver, by the exclusive functioning of the bevel, then the inventory of the Observatory may well be part of a different dynamic, marked by greater functional and conceptual handling.

The flexibility of the tool with cortical bevel of the Observatory, unlike the strictly speaking cleaver, and the differences observed with the Large Flakes Industries of the Iberian Peninsula and North Africa, lead us to consider the assumption of an autonomous and potentially isolated innovation. If the specific need answered by this innovation eludes us, we can notice that it was part of a macrolithic trajectory, turned toward looking for versatile tools, standardized by a predetermined flake debitage. In our context of study, looking for flakes with terminal bevel, characterized by transformative parts with biplane section of 30 to $40^{\circ}$, could represent the most effective, or even unavoidable, physical solution, to use the soft limestone available locally.

86 At the end of our study, we therefore minimize the hypothesis of a relationship between the technical traditions of the Observatory and those of the Iberian peninsula, although we recognize the enigmatic characteristics surrounding the origin and 
development of this technical phenomenon in Western Europe, probably during isotopic stages 8 and 7. At most we should remember that the bevel tools are found independently in different contexts, as in the Acheulean of Barbas (called typo-bevel: Boëda et al. 1996) or the Middle Stone Age of Sibudu (Conard et al. 2012). The cleaver reappears in Western Europe during the Vasconian (Bordes 1953; Deschamps 2010), phase of a late middle Palaeolithic that seems to consecrate the hypothesis of technical convergence (Deschamps 2014).

\section{To conclude}

The first aim of this study was to take part in the discussions about the nature and significance of the technical traditions that cross the Early Palaeolithic in Western Europe. We rested our reflection on the almost unpublished series of the large flakes from the Observatory, whose originality could make us forget the old age of the excavation context. These large flakes led us to address the issue of cultural areas, developing a comparison with industries with large flakes and cleavers 0 in the Iberian Peninsula and North Africa. At the end of the study, we minimize the hypothesis of a direct relationship between these large flakes industries and that of the Observatory and we are considering that of a local origin.

From the series of the Observatory cave, we were able to recognize a new chaine operatoire of flake-cleavers production or flakes with cortical bevel, called "Observatory debitage". This preferential debitage with single sequence operates through compliance with some rules that take advantage of carefully selected natural volumes. This debitage reflects the control of simple geometric rules that favoured the development of the fracture front so that the two edges of the predetermined flake differed. The knappers have adapted to the available materials and sought specific morphologies they transformed using an efficient operating scheme. The absence of recurrence, or the inability to reconfigure the volume identically, is likewise an element that characterizes this production system and its principles of predetermination. This lack of recurrence emphasizes with interest the narrowness of the conceptual relationship (a dead end?) between firstly the opportunity created by the knapper from a natural configuration, and secondly the normalization of the functional criteria towards which the technical system seems to aim.

Finally, this study has allowed us to raise a discussion on the specifics of the cleaver tool, in the history of techniques and in its structural characteristics on human societies. This tool, structured on a raw bevel, crosses the Palaeolithic but nevertheless remains characteristic of earlier periods. Massive, it refers back to societies that also recognized each other by a mode of perception of the mineral resources and a territorial organization that remain today still partially unknown. 


\section{BIBLIOGRAPHY}

ALIMEN M.-H. 1975 - Les «isthmes» hispano-marocain et sicilo-tunisiens aux temps acheuléens, L'Anthropologie, Paris, 79, 3, p. 399-436.

BARRAL L., SIMONE S. 1967 - Nouvelles fouilles à la grotte du Prince (Grimaldi, Ligurie italienne). Découverte de Paléolithique inférieur. Bull. Mus. Anthropol. Prehist. Monaco 14, p. 5-23.

BARRAL L., SIMONE S. 1972 - Le Mindel-Riss et le Riss à la grotte d'Aldène (Cesseras, Hérault), Bull. Mus. Anthropol. Prehist. Monaco, 18, p. 45-68.

BOËDA E. 1994 - Le concept Levallois : variabilité des méthodes, Paris, CNRS, 280 p.

BOËDA E. 2013 - Techno-logique et technologie : une paléo-histoire des objets tranchants. Archéoédition.com. 259 p.

BOËDA E., KERVAZO B., MERCIER N., VALLADAS H. 1996 - Barbas C'3 base (Dordogne), une industrie bifaciale contemporaine des industries du Moustérien ancien : une variabilité attendue, In : A. Bietti. et S. Grimaldi (Éds.), Proceedings of the International Round Table: Reduction processes («chaînes opératoires») for the European Mousterian, Rome, Quaternaria Nova VI, p. 465-504.

BORDES F. 1953 - Essai de classification des industries « moustériennes », Bulletin de la Société Préhistorique Française. L, 7-8, p. 457-466.

BORDES F. 1966 - Acheulean cultures in southwest France. In : D. Sen et S. Ghosh, S (Éds), Studies in Prehistory - Robert Bruce Foote memorial volume, Calcutta, p. 49-63.

BOSINSKI G. 2006 - Les premiers peuplements de l'Europe centrale et de l'Est. C. R. Palevol 5, p. 311-317

BOULE M., VILLENEUVE L. de 1927 - La grotte de l'Observatoire à Monaco, Archives de l'Institut de Paléontologie Humaine. 113p.

BREUIL H. 1924 - Hache taillée en quartzite, Bulletin de la Société Préhistorique Française, 21, p. 253-254.

BREUIL H. 1932 - Le Paléolithique ancien en Europe Occidentale et sa Chronologie. Bulletin de la Société préhistorique de France, 29, 12. p. 570-578

BREUIL H., KELLEY H. 1954 - Le Paléolithique ancien. Bulletin de la Société préhistorique de France. 51, 8. p. 9-26.

CAUCHE D. 2012 - Productions lithiques et comportements techno-économiques de groupes humains acheuléens et moustériens en région liguro-provencale, C. R. Palevol, 11, p. 519-527

CHEVRIER B. 2012a - Les assemblages à pièces bifaciales au Pléistocène inférieur et moyen ancien en Afrique de l'Est et au Proche-Orient : nouvelle approche du phénomène bifacial appliquée aux problématiques de migrations, de diffusion et d'évolution locale. Thèse de l'Université de Paris XNanterre.

CHEVRIER B. 2012b - Ni espace ni temps en Préhistoire ancienne. «Out of Africa» ou le paradigme de la flèche. M@ppemonde, 106, 19 p.

CONARD N.J., PORRAZ G., WADLEY L. 2012 - What is in a name, characterizing the "postHowiesons Poort" at Sibudu. South African Archaeological Bulletin, 67(196), p. 180-199 
DESCHAMPS M. 2010 - Le Vasconien : révision de sa signification à partir des industries lithiques d'Olha I et II, d'Isturitz et de Gatzarria PALEO, 21, p. 103-126

DESCHAMPS M. 2014 - La diversité culturelle au Paléolithique moyen récent : le Vasconien et sa signification au sein des faciès moustériens. Thèse de Doctorat de l'Université de Toulouse. 580p.

FALGUERES C., YOKOYAMA Y., QUAEGEBEUR J.P. 1988 - Datations de sédiments quaternaires par la méthode de résonance de spin électronique (ESR). L'Anthropologie 92 (2), p. 723-725.

FALGUERES C., AJAJA O., LAURENT M., BAHAIN J.-J. 1991 - Datation de la grotte d'Aldène (Cesseras, Hérault), Comparaison par les méthodes du déséquilibre de la famille de l'uranium et de la résonnance de spin électronique, Bulletin du Musée d'Anthropologie de Monaco, 34, p. 17-27.

FALGUERES, C., YOKOYAMA, Y., SHEN, G., BISCHOFF, J.L., KU, T.L., LUMLEY H. de 2004 - New Useries dates at the Caune de l'Arago, France. Journal of Archaeological Science 31, p. 941-952.

FEBLOT-AUGUSTINS J. 1997 - La circulation des matières premières au Paléolithique, Liège, ERAUL nº $75.536 \mathrm{p}$.

GAGNIERE S. 1970 - Provence-Côte-d'Azur-Corse. In: Gallia préhistoire. 13(2), p. 551-583.

GAGNEPAIN J., GAILLARD C. 2005 - La grotte de la Baume Bonne (Quinson, Alpes de HauteProvence) : synthèse chronostratigraphique et séquence culturelle d'après les fouilles récentes (1988-1997). BAR Int. Series 1364, p. 73-85.

GENESTE J.-M., PLISSON H. 1996 - Production et utilisation de l'outillage lithique dans le Moustérien du Sud-Ouest de la France : les Tares à Sourzac, Vallée de l'Isle, Dordogne, In : A. Bietti et S. Grimaldi (Éds), Proceedings of the International Round Table: Reduction processes («chaînes opératoires») for the European Mousterian, Rome, Quaternaria Nova VI, p. 343-367.

GREGOIRE S., MOIGNE A.M., BARSKY D., LUMLEY de H., 2007 - Gestion et sélection des ressources au sein d'un territoire. Un exemple de comportement économique au Paléolithique inférieur dans le sud de la France. In : Moncel, M.-H., Moigne, A.-M., Arzarello, M., Peretto, C. (Eds.), Aires d'approvisionnement en matières premières et aires d'approvisionnement en ressources alimentaires. Approche intégrée des comportements. Workshop 23, XV Congrès UISpP, 4-9 septembre 2007 Lisbonne. BAR International Series 1364, vol. 5.

GRIFONI R., TOZZI C. 2006 - L'émergence des identités culturelles au Paléolithique inférieur : le cas de l'Italie. Comptes Rendus Palévol, 5, p. 137-148.

HEINZELIN DE BRAUCOURT J. de 1962 - Manuel de typologie des industries lithiques. Bruxelles, Institut Royal des Sciences Naturelles Belges, 74 p.

KLEINDIENST M.R. 1962 - Components of the East African Acheulian assemblage: an analytic approach. In: Mortelmans, G. (Ed.), Actes du IVeme Congrès Panafricain de Préhistoire et de l'Etude du Quaternaire, vol 40. Musée Royal de l'Afrique Centrale, Tervuren (Belgique), p. 81-105.

KUHN S.L. 1995 - Mousterian Lithic Technology: An Ecological perspective. Princeton University Press.

LHOMME V. 2007 - Tools, space and behaviour in the Lower Palaeolithic: discoveries at Soucy in the Paris basin. Antiquity, 81, p. 536-554.

LUMLEY H. de 1960 - Clactonien et Tayacien dans la région méditerranéenne française. ????

LUMLEY-WOODYEAR H. de 1969 - Le Paléolithique inférieur et moyen du Midi méditerranéen dans son cadre géologique, Ve supplément à Gallia Préhistoire, 2 vol., 453 p. et 445 p. 
LUMLEY H. de 1976 - Les civilisations du Paléolithique inférieur en Provence, In : H. de Lumley (Éd.) La Préhistoire française - $t$. I : Les civilisations paléolithiques et mésolithiques., Ed. du CNRS, p. 819-851.

LUMLEY H.de, LUMLEY M-A. de, MISKOVSKY J-C., RENAULT-MISKOVSKY J. 1976 - Le site de Terra-Amata - Impasse Terra Amata, Nice, Alpes-Maritimes, in : H. de Lumley et L. Barral (Éds), Sites paléolithiques de la région de Nice et Grottes de Grimaldi - Livret-guide de l'excursion B1 - IX ${ }^{e}$ Congrès de l'UISPP, Nice, p. 15-49.

LUMLEY H. de, AROBBA D., CAUCHE D., DESCLAUX E., ÉCHASSOUX A., KHATIB S., RICCI M., ROUSSEL B., SIMON S., TOZZI C., VALENSI P., VICINO G. 2008 - Les cultures acheuléennes et moustériennes dans les Alpes-Maritimes et en Ligurie. Bull. Mus. Anthropol. Prehist. Monaco, suppl. 1, p. 11-20.

LUMLEY DE, H., FALGUERES C., MICHEL V., YOKOYAMA Y. 2009 - Datations des formations pléistocènes du site acheuléen de Terra Amata. In : Lumley de, H. (Ed.), Terra Amata. Nice, AlpesMaritimes, France. Tome I. Cadre géographique - Historique - Contexte géologique-StratigraphieSédimentologie-Datation. CNRS Éditions, Paris, p. 469-486.

MICHEL V, SHEN G, SHEN C-C, WU C-C, VERATI C, GALLET S., MONCEL M.H., COMBIER J., KHATIB S., MANETTI M. 2013 - Application of U/Th and ${ }^{40} \mathrm{Ar} /{ }^{39} \mathrm{Ar}$ Dating to Orgnac 3, a Late Acheulean and Early Middle Palaeolithic Site in Ardèche, France. PLoS ONE 8(12): e82394

MONCEL M-H, MOIGNE A-M, YOUSSEF S, COMBIER J. 2011 - The Emergence of Neanderthal Technical Behavior: New Evidence from Orgnac 3 (Level 1, MIS 8), Southeastern France. Current Anthropology 52, p. 37-75.

MOURRE V. 2003 - Implications culturelles de la technologie des hachereaux. Unpublished Ph. D. dissertation, University of Paris X-Nanterre. 3 tomes, 303 p., 259 p. et 333 p.

MOURRE V. 2006 - Emergence et évolution de la prédétermination au Paléolithique. In : Astruc L., Bon F., Léa V., Milcent P.-Y., Philibert S. (Eds) Normes techniques et pratiques sociales. De la simplicité des outillages pré- et protohistoriques. $\mathrm{XXVI}^{\mathrm{e}}$ rencontres internationales d'archéologie et d'histoire d'Antibes. Editions APDCA, Antibes, p. 61-74

MOURRE V., COLONGES D. 2010 - La question du débitage de grands éclats à l'Acheuléen. In : Mourre V., Jarry M. (Eds) Entre le Marteau et l'enclume... La percussion directe au percuteur dur et la diversité de ses modalités d'application. Actes de la table ronde de Toulouse, 15-17 mars 2004, Paleo, numéro spécial, p. 35-48

NICOUD É. 2010 - The Acheulian in Western Europe : Technical systems and peopling patterns of Europe, in S.A. Vasil'ev et V.E. Schelinsky, SPb (ed.), The earliest inhabitants of the Caucasus and Hominid dispersals at Eurasia,: Sankt-Petersburg Centre for Oriental Studies Publishers, p. 197-210.

NICOUD É. 2011 - Le phénomène Acheuléen en Europe occidentale : approche chronologique, technologie lithique et implications culturelles, Thèse de doctorat, Université de Provence et Università degli Studi di Roma « La Sapienza », 483 p.

NICOUD É., 2013a - Le paradoxe Acheuléen. Comité des Travaux Historiques et Scientifiques, Documents Préhistoriques 32/ Bibliothèque des Ecoles françaises d'Athènes et de Rome $356 \mathrm{p}$.

NICOUD É. 2013b - What Does the Acheulean Consist of? The Example of Western Europe (MIS 16-9) Mitteilungen der Gesellschaft für Urgeschichte - 22. P. 41-60

OTTE M. 1996 - Le paléolithique inférieur et moyen en Europe, Paris, Masson \& Armand Colin, 296 p.

PALMA DI CESNOLA A. 2001 - Il Paleolitico inferiore e medio in Italia. Firenze, Museo Fiorentino di Preistoria « Paolo Grazioso », 352 p. 
PELEGRIN J. 1995 - Technologie lithique : le Châtelperronien de Roc-de-Combe (Lot) et de La Côte (Dordogne), Paris, CNRS Editions, Cahiers du Quaternaire $n^{\circ} 20,297 \mathrm{p}$.

PORRAZ G., NEGRINO F. 2008 - Espaces économiques et approvisionnement minéral au Paléolithique moyen dans l'aire Liguro-provençale. In : D. Binder, X. Delestre et P. Pergola (Eds.) Archéologies transfrontalières (Alpes du Sud, Côte d'Azur, Piémont et Ligurie). Bilan et perspectives de recherche. Actes du colloque de Nice 13-15 décembre 2007. Bulletin du Musée d'Anthropologie de Monaco, p. 29-40

PORRAZ G., SIMON P., PASQUINI A. 2010 - Identité technique et comportements économiques des groupes proto-aurignaciens à la grotte de l'Observatoire (Principauté de Monaco), Gallia Préhistoire, 52, p. 33-59.

POTTIER G. 1938 - La chronologie du Paléolithique inférieur (Acheuléen et Clactonien). Bulletins et Mémoires de la Société d'anthropologie de Paris, VIII, 9, 4-6, p. 69-72.

ROCCA R. 2013 - Peut-on définir des aires culturelles au Paléolithique inférieur ? Originalité des premières industries lithiques en Europe centrale dans le cadre du peuplement de l'Europe. Thèse de l'Université de Paris X-Nanterre.

ROCHE H., TEXIER P-J. 1991 - La notion de complexité dans un ensemble lithique. Application aux séries acheuléennes d'Isenya (Kenya), In : 25 ans d'Etudes technologiques en Préhistoire, Juan-les-Pins, XIèmes Rencontres Internationales d'Archéologie et d'Histoire d'Antibes, Ed. ADPCA, p. 99-108.

SANTONJA M. 1996 - The Lower Palaeolithic in Spain: sites, raw material and occupation of the land. In: N. Moloney, L. Raposo et M. Santonja (Éds), Non-flint stone tools and the Palaeolithic occupation of the Iberian Peninsula, Tempus Reparatum, BAR International Series 649, p. 1-20.

SANTONJA M., VILLA P. 2006 - The Acheulean of Western Europe. In : Goren-Inbar, N. and Sharon, G. (eds.), Axe Age - Acheulian Tool-making from Quarry to Discard. London: Equinox Publishing, p. 429-478.

SHARON G. 2007 - Acheulean large flake industries: Technology, chronology, and significance. BAR (British Archaeological Reports) International Series 1701. Oxford: Archaeopress. 320 p.

SHARON G. 2008 - The impact of raw material on Acheulian large flake production. Journal of Archaeological Science 35, p. 1329-1344

SHARON G. 2009 - Acheulian Giant-Core technology. A worldwide perspective. Current Anthropology 50, 3, p. 335-367

SHARON G. 2011 - Flakes crossing the straits? Entame flakes and northern Africa-Iberia contact during the Acheulean. African Archaeological Review 28, p. 125-140

SIMON P. 2008 - Les grottes des Balzi Rossi : Historique des découvertes. La nascita della paletnologia in Liguria: personaggi, scoperte e collezioni tra XIX ${ }^{e}$ XX secolo: atti..., 15, p.171.

SIMONDON G. 1958 - Du mode d'existence des objets techniques. Paris, Ed. Aubier

SIMONE S. 1993 - Préhistoire de Monaco. Bulletin du Musée d'Anthropologie Préhistorique de Monaco, 36 , p. 59-63.

SIMONE S. 2008 - Le Pléistocène moyen à la grotte du Prince (Ligurie italienne). Arch. Instit. Paleontol. Hum. 39, p. 89-94.

TAVOSO A. 1986 - Le Paléolithique inférieur et moyen du Haut-Languedoc. Gisements des terrasses alluviales du Tarn, du Dadou, de l'Agout, du Sor et du Fresquel, Université de Provence, Ed. du Laboratoire de Paléontologie Humaine et de Préhistoire, Etudes Quaternaires, 5, (1978), 404 p. 
TOMASSO A., BINDER D., SIMON P., PORRAZ G., MARTINO G. Soumis - Entre Rhône et Apennins : le référentiel MP-ALP, matières premières de Provence et de l'arc ligure. In : A. Tomasso, D. Binder, G. Martino, N. Naudinot (Eds.) Ressources lithiques, productions et transferts entre Alpes et Méditerranée. Séance de la société préhistorique française organisée à Nice les 28 et 29 Mars 2013.

TEXIER P.-J. 1996 - Evolution and diversity in flaking techniques and methods in the Palaeolithic, In : Oltre la pietra - Modelli e tecnologie per capire la preistoria, Forlí, XIII UISPP Congress, A.B.A.C.O. Ed, p. 281-321.

TEXIER P.-J., ROCHE H. 1995 - The impact of predetermination on the development of some acheulean chaînes opératoires. In: Evolucion humana en Europa y los yacimientos de la Sierra de Atapuerca. Junta de Castilla y Leon, Vol. 2, p. 403-420.

TIXIER J. 1956 - Le hachereau dans l'Acheuléen nord-africain. Notes typologiques. Congrès Préhistorique de France. XVe session, Poitiers-Angoulême, p. 914-923.

TIXIER J., INIZAN M.-L., ROCHE H., DAUVOIS M. 1980 - Préhistoire de la pierre taillée - 1. terminologie et technologie, Paris, CREP, 120p.

TURQ A. 2000 - Paléolithique inférieur et moyen entre Dordogne et Lot. Paleo, supplément $2 ; 456$ p.

VILLA P. 1983 - Terra Amata and the Middle Pleistocene Archaeological Record of Southern France. Anthropology 13, University of California Press, Berkeley and Los Angeles. 303 p.

VILLA P. 1991 - Middle Pleistocene prehistory in southwestern Europe: the state of our knowledge and ignorance. Journal of Anthropological Research 47, p. 193-218.

\section{NOTES}

5. The dimensions have been calculated from a reference point reported on the map of the Observatory Cave by the surveyors Rollin (21/12/1989) and positioned at an altitude of 89.47.This reference point $\left(n^{\circ} 7\right)$ is fixed in the karst at the foot of the brecciated level.

\section{ABSTRACTS}

The excavations at the Observatoire Cave (Principality of Monaco), have been well published in the first volume of the Archives of the Institut de Paleontologie humaine in 1927. The authors document the presence in the "foyer $k$ » of large flakes also called soucoupes (saucers or flying saucers in french) by L. de Villeneuve. The study of this lithic collection ( $N=132)$ indicates a production of trapezoidal to quadrangular flakes, detached on limestone cobbles that were cautiously selected, prepared and shortly exploited for one unique preferential product. These large flakes have been structured on a cortical distal end (or biseau), never retouched and characterized by a fine angle, a biplane section and a slightly convex delineation. In a technofunctional perspective, these large flakes clearly overlap the definition of the cleavers. This collection from the Observatoire Cave, which precedes $230000 \mathrm{BP}$, also includes a series of cobbles ( $\mathrm{N}=159)$ and one single handaxe. This lithic assemblage finds no regional equivalent, but comparisons can be made with some Acheulean Large Flake Industries from Spain and Northern 
Africa, characterized by a production of entames and the shaping of proto-cleavers (or type 0 ). The soucoupes of the Observatoire Cave encourage us to develop further on the peculiarities of this macrolithic technology and on their signification in a regional and Mediterranean context. Our study finally challenges the hypothesis of diffusion and consider the scenario of a local invention as plausible, within a framework of a technology that was closely adapted to the nature of the raw material.

Les fouilles de la grotte de l'Observatoire (Principauté de Monaco), remarquablement publiées dans le premier tome des Archives de l'Institut de Paléontologie Humaine en 1927, avaient révélé la présence dans le «foyer $\mathrm{k}$ » d'une vieille industrie composée d'éclats en calcaire de très grandes dimensions, autrement appelés soucoupes par Léonce de Villeneuve. La reprise pour étude de cet assemblage lithique $(\mathrm{N}=132)$ indique une recherche d'éclats normalisés, de morphologie trapézoïdale à quadrangulaire, débités aux dépens de volumes soigneusement sélectionnés, aménagés et exploités selon un débitage préférentiel à séquence unique. Ces grands éclats, structurés autour d'un biseau cortical brut de débitage, fin, biplan, rectiligne à légèrement convexe, recouvrent la définition du hachereau d'un point de vue techno-fonctionnel. Cette collection de la grotte de l'observatoire, également composée de galets manuportés $(\mathrm{N}=159)$ et d'un biface, aurait un âge antérieur à 230000 ans BP. À ce jour, cette série ne trouve aucun équivalent régional mais des rapprochements peuvent être effectués avec les «Large Flakes Industries » d'Espagne et d'Afrique du Nord, caractérisées par un débitage d'entames et la présence de hachereaux de type 0 . Les soucoupes de la grotte de l'observatoire conduisent à nous interroger sur les spécificités de cette technologie macrolithique et sur sa signification dans un contexte régional et méditerranéen. Notre étude nous amène finalement à discuter de l'hypothèse de la diffusion pour envisager celle d'une apparition locale, dans le cadre d'un savoirfaire technique qui se serait étroitement adapté à la nature du matériau d'œuvre.

\section{INDEX}

Mots-clés: Paléolithique ancien, Acheuléen, Méditerranée, grands éclats, calcaire, hachereau, débitage de l'Observatoire, diffusion, convergence

Keywords: Early Paleolithic, Acheulian, Mediterranean, Large flakes, cleaver, limestone, « Observatoire » debitage, diffusion, convergence

\section{AUTHORS}

\section{GUILLAUME PORRAZ}

CNRS, USR 3336, UMIFRE 25, Institut Français d'Afrique du Sud (IFAS), 62 Juta Street, Braamfontein, Johannesburg, Afrique du Sud. guillaume.porraz@ifas.co.za

\section{ÉLISA NICOUD}

École Française de Rome, Piazza Farnese, 67, I-00186 Roma - elisa.nicoud@gmail.com

\section{MICHEL GRENET}

UMR 5608 TRACES, Maison de la Recherche, Université de Toulouse II - le Mirail, 5 allée Antonio Machado, FR-31058 Toulouse - archelmi@gmail.com 


\section{PATRICK SIMON}

Directeur du Musée d'Anthropologie Préhistorique de Monaco, 56bis Boulevard du Jardin Exotique, MC-98000 Monaco - patrick.simon@map-mc.com 